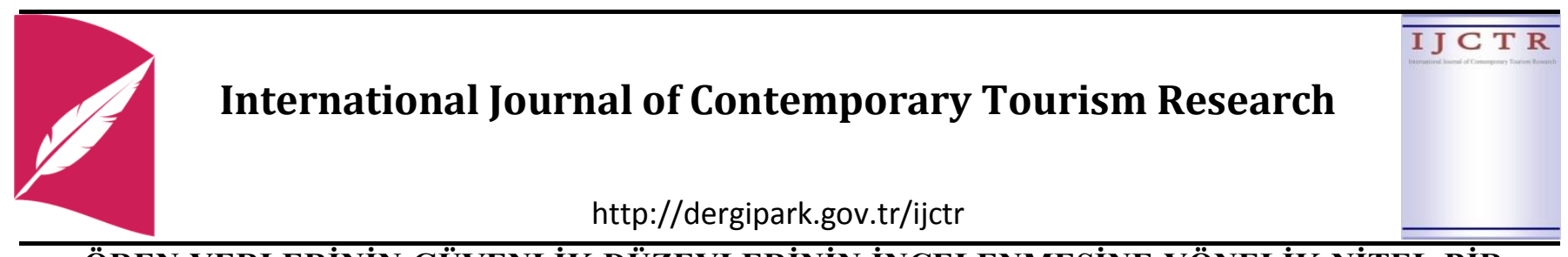

ÖREN YERLERINIIN GÜVENLIKK DÜZEYLERİNIN İNCELENMESİNE YÖNELİK NITTEL BİR ARAŞTIRMA: AYDIN İLI ÖRNEĞİ

Araştırma Makalesi

Cihat BILLGiN ${ }^{1}$, Vedat ACAR $^{2}$, Abdullah TANRISEVDi $^{3}$

\title{
ÖZET
}

$\mathrm{Bu}$ araştırmada, ören yerlerinin güvenlik düzeylerini ortaya koymak amaçlanmaktadır. $\mathrm{Bu}$ amaç doğrultusunda, Aydın ili sınırları içerisinde yer alan ve turist grupları tarafından ziyaret edilen 8 ören yeri araştırma kapsamında incelenmiştir. Nitel araştırma deseni belirlenen bu araştırma verilerinin toplanmasında, "doğal-katılımsız gözlem" yöntemine başvurulmuştur. Araştırmada öncelikle, Kültür ve Turizm Bakanlığı'na bağlı Teftiş Kurulu Başkanlığı'nın 2863 Sayılı Kültür ve Tabiat Varlıklarını Koruma Kanunu mevzuatından, Kültür ve Turizm Bakanlığı Yatıım ve İşletmeler Genel Müdürlüğü’nün raporlarından ve Türkiye Cumhuriyeti İçişleri Bakanlığı Emniyet Genel Müdürlüğü Kaçakçılık ve Organize Suçlarla Mücadele Daire Başkanlığı'nın raporlarından faydalanılarak, 17 maddeden oluşan bir gözlem formu oluşturulmuştur. Daha sonra, 15-21 Ocak tarihleri arasında, gözlem formunda belirtilen maddelerle ilgili uzman görüşüne başvurulmuştur. Uzman görüşleri neticesinde, gözlem formunda yapılan düzenlemeyle birlikte 20 maddeden oluşan gözlem formu, öncelikle Afrodisias ve Nysa ören yerlerinde gözlemlenmeye çalışılmıştır. Yapılan pilot çalışma neticesinde, 1 maddenin gözlemlenmesi mümkün olmaması nedeniyle gözlem formundan çıkarılmıştır. Daha sonra, 11-17 Şubat 2020 tarihleri arasında, Aydın ili sınırları içerisinde bulunan 23 ören yerinden Kültür ve Turizm Bakanlığı tarafından turistik ziyarete açık olup turistler tarafından ziyaret edilen diğer 6 ören yerinde gözlemler gerçekleştirilmiştir. Gözlemlerin güvenirliliğini arttırmak adına profesyonel turist rehberi olan birinci yazar ile birlikte başka bir gözlemci (profesyonel turist rehberi) daha görev almıştır.

Anahtar Kelimeler: Katılımsız Gözlem, Güvenlik Düzeyi, Ören yeri, Nitel Araştırma

\section{JEL Kodları:}

\section{A QUALITATIVE RESEARCH TOWARDS INVESTIGATING THE SECURITY LEVELS OF ARCHAEOLOGICAL SITES: THE CASE OF AYDIN PROVINCE \\ Research Article}

\begin{abstract}
In this study, it is aimed to reveal the security levels of the ancient cities. In accordance with this purpose, 8 archaeological sites which are located within the borders of Aydin province and visited by tourist groups were investigated within the scope of the research. The data of this research which was determined as qualitative research design was collected by the method of "Natural-non-participant observation". For this research, firstly an observation form comprised of 17 items was created by making use of the law on the Conservation of Cultural and Natural Property of the "Board of Inspection of the Ministry of Culture and Tourism" and the reports of "General Directorate

\footnotetext{
1 Bilim Uzmanı, Aydın Adnan Menderes Üniversitesi, Sosyal Bilimler Enstitüsü, Turizm İşletmeciliği Anabilim Dalı, cihatbilgin@outlook.com,orcid.org/0000-0001-8560-1144

${ }^{2}$ Dr. Öğr Üyesi, Aydın Adnan Menderes Üniversitesi, Turizm Fakültesi, acrvdt@ gmail.com, orcid.org/0000-0002-1679-6360

${ }^{3}$ Prof. Dr., Aydın Adnan Menderes Üniversitesi, Turizm Fakültesi, atanrisevdi@ gmail.com, orcid.org/0000-0002-6640-2008

"Bilgin C., Acar V. ve Tanrısevdi A. (2020). Ören Yerlerinin Güvenlik Düzeylerinin İncelenmesine Yönelik Nitel Bir Araştırma: Aydın İli Örneği, International Journal of Contemporary Tourism Research, Vol 4: No: 1, p. 91-110, doi: 10.30625/ijctr.723292”
} 
of Investments and Enterprises" and "Department of Anti-Smuggling and Organized Crime". Then, for the items of observation form, experts were consulted between 15-21 January. With the arrangement made in the observation form as a result of the expert opinions, the observation form consisting of 20 items was tried to be observed primarily in the archaeological sites of Aphrodisias and Nysa. As a result of the pilot study, 1 item was removed from the observation form since it was not possible to observe. Then, between 11 and 17 February 2020, the observations were made in the six of 23 archaeological sites situated within the borders of Aydin province which are available for tourist visits by the Ministry of Culture and Tourism. Along with the first writer who is a professional tourist guide, another observer (professional tour guide) was assigned in order to increase the reliability of the observations.

Keywords: Non-participant Observation, Security Levels, Archaeological Site, Qualitative Research.

\section{JEL Classification Code:}

\section{GÍRIŞ}

İnsanların etkileşimleri sonucu ortaya çıkan kültür olgusu geçmişten günümüze kadar birçok somut ve soyut eserin oluşmasına katkıda bulunmuştur. Somut olan eserlerin yüzy1llar boyunca kuşaktan kuşağa aktarılarak miras olarak korunulması adeta toplumların bir vazifesi haline gelmiş bulunmaktadır. Kuşaklar arası bırakılan bu kültürel miraslar, savaşlar sonrasında sınırları belirlenen ülkeler tarafından zamanla fark edilmeye başlanmıştır. Özellikle 17. yüzyıldan sonra Avrupa genelinde ilerleyen teknoloji ve sanayi, halkın ekonomik açıdan gelişmesini beraberinde getirmiştir. Ekonomik sorunlarını gidermeye çalışan bireylerin ise tarihi eserlere olan ilgileri çoğalmış ve kökeni çok eskiye dayanan koleksiyonculuk faaliyetleri artmaya başlamıştır. Koleksiyonculuk faaliyetlerindeki artış, müze sayılarındaki artışı beraberinde getirmiştir (Uralman, 2006). Özmen'e (2018) göre Avrupa'da müzecilik, üç etapta gelişim göstermiştir: Rönesans'a kadar süren koleksiyonerlik süreci; Rönesans'tan 19. yüzyıla kadar süren kurumsallaşma süreci; bugün hala daha devam ediyor olan eğitimsel kurumsallaşma sürecidir. Koleksiyonerlik süreci, müzelerin ortaya çıkmasında büyük rol oynayan bir süreçtir. Bu tarz faaliyetler ve gelişmeler sonucunda kültürel ve tarihsel açidan zengin Anadolu ve birçok ülke, Avrupalı devletler ve seyyahlar tarafindan yağmalanmaya başlanmıştır.

Anadolu geçmişten bugüne kadar çeşitli medeniyetlere ev sahipliği yapmıştır. Bu süreçteki son medeniyetler arasinda yer alan Osmanlı Devleti'nin başlattığı eski eser koruma düzenlemeleri, Türkiye Cumhuriyeti yasa ve mevzuatlarıyla son halini bulmuştur. Tüm bunlara rağmen günümüzde tarihi eser kaçakçıllı̆ $\breve{1}_{1}$ devam etmektedir. Kültürel mirasın önemli bir parçası olan kültür varlıklarının insanlar tarafından tahribata uğraması ise kültürlere ve insanlığın geçmişine zarar verecek duruma gelmiştir. Töngür (2018), Türkiye'nin arkeolojik alanların yağmalanması ve kaçakçılıkla uğraşan kaynak ülkeler arasında yer aldığını ifade etmiştir. Bunun temel sebeplerinden birisi olarak Türkiye'nin dört bir yanının taşınır ve taşınmaz kültür varlıkları ile dolu olması gösterilebilir.

Türkiye'de kültür varlıklarının korunmasını sağlayan ana mevzuatın 2863 sayılı Kültür ve Tabiat Varlıklarını Koruma Kanunu olduğu bilinmektedir. Ayrıca taşınır ve taşınmaz kültür varlıklarını koruyan başta UNESCO (Birleşmiş Milletler) olmak üzere birçok kurum ve kuruluşlar bulunmaktadır Ülkemizde tüm bu düzenlemelere rağmen 2017'de yapılan tarihi eser kaçakçıllı̆ 1 operasyonlarında 997 kişi; 2018 yılında yapılan operasyonlarda ise 1251 kişi hakkında yasal işlem yapılmıştır. Diğer yandan Kaçakçılık ve Organize Suçlarla Mücadele Daire Başkanlığı tarafindan 2017 y1lında 496 operasyon gerçekleştirilirken 2018 yılında 604 operasyon gerçekleştirilmiştir (Emniyet Genel Müdürlüğü Kaçakçılık ve Organize Suçlarla Mücadele Daire Başkanlığı, 2019). İstatistikler dikkate alındığında, vakaların gün geçtikçe engellenmeye çalışılmasına rağmen vaka sayısında bir artışın söz konusu olduğu anlaşılmaktadır.

Kültür varlıklarının kaçakçılığının yaşandığı yerlerin, ören yerlerini kapsayan arkeolojik sit alanı olarak belirlenmiş bölgeler, olduğu görülmektedir (Emniyet Genel Müdürlüğü Kaçakçılık ve Organize Suçlarla Mücadele Daire Başkanlığ 1 , 2014). Ören yerlerinin tüm bu yasa ve mevzuatlara rağmen korunması ve gelecek kuşaklara aktarılması için öncelikle koruma altına alınması gerektiği kaçınılmaz bir zorunluluktur. $\mathrm{Bu}$ noktadan hareketle çalışmanın temel araştırma sorusu "ören yerlerinin güvenlikleri ne düzeydedir?" şeklinde belirlenmiştir. Bu amaç 
sorusu doğrultusunda, alt araştırma soruları aşağıdaki şekilde oluşturulmuştur:

- Ören yeri koruma alanı, nasıl muhafaza altına alınmıştır?

- Ören yeri iç bölgesinde yerleşim katmanlarını tehdit eden herhangi bir imar faaliyeti var midir?

- Ören yerinin korunması nasıl sağlanmaktadır?

- Ören yeri korunmasına yönelik mesai saatleri dışında nasıl bir uygulama gerçekleştirilmektedir?

- Ören yerini ziyaret eden ziyaretçiler, herhangi bir kontrolden (x-ray cihazı, el dedektörü gibi) geçmekte midir?

- Olas1 bir elektrik kesintisi, sabotaj, yangın, hırsızlık gibi durumlara yönelik ören yerinde ne tür önlemler alınmıştır?

- Ören yeri içerisindeki eserlerin korunmasına yönelik ne tür uyarı levhalarına başvurulmaktadır?

\section{KAVRAMSAL ÇERÇEVE}

Anadolu, geçmişten bugüne kadar yüzyıllar boyunca birçok medeniyete ev sahipliği yapmıştır. Türkiye topraklarından geçen bu medeniyetler günümüze kadar varlığını sürdürecek sayısız eser ve yap1 bırakmıştır. Geçmişte yaşanılan savaşlardan ve fetihlerden ötürü bırakılan bu eserlerin değeri pek bilinmeyip birçok eski yap1 tahrip edilmiş veya çeşitli sebeplerle yıkılmıştır. Geriye kalan eski yerleşim yapıları ve eserlerin çoğu, zaman içerisinde toprak altında kalmaya yüz tutmuştur.

Günümüzde, geçmişten bugüne kadar Anadolu coğrafyasında kalan tüm bu tarihi eserler "kültür varlıkları" adı altında toplanmıştır. Kültür varlıklarının kaçakçılığının ve tahribatının tam olarak hangi tarihte başladığını söylemek mümkün değildir. Fakat tarihi eserlerin kaçakçıllğının ülkemizde başlamasının nedeni olarak, 17. yüzyılda Avrupa'da gelişmeye başlayan koleksiyonculuk ve müzecilik faaliyetleri gösterilmektedir. Avrupa ülkelerinden gelen seyyahlar, kötü niyetli kişiler kaçak kazılar yaparak, eserleri ve yapıları gün yüzüne çıkarıp ağırlıklı olarak Avrupa'daki ülkelerine götürmüştür. Avrupa'daki müzelerin çoğu bu yağmalamalardan meydana gelmiştir. $\mathrm{Bu}$ tarz kaçak ve gizli faaliyetler 20. yüzyılın ortalarına doğru azaldığından söz edilebilir (Karaduman, 2007: 19). Bunun temel sebeplerinden birisi ise
Osmanlı Devleti'nin tarihi eserleri kapsayan kültür varlıklarının korunmasıyla ilgili önlem alarak kanun çıkarması ve günümüzde bu kanunların yeniden düzenlenerek Türkiye Cumhuriyeti'nde devam ettirilmesi olduğu söylenebilir.

Osmanlı Devleti'nde batılılaşma sürecinde kültür varlıklarının korunması ile ilgili çıkarılan ilk düzenleme 1869 yılında oluşturulan Âsar-1 Atika Nizamnamesi'dir. $\mathrm{Bu}$ düzenlemenin temel amac1 bazı taşınır kültür varlıklarına tanım getirmek ve Osmanlı Devleti sınırları içerisinde yer alan arkeolojik yapılarda kazı yapan yabancı ekiplerin çalışmalarını denetlemek olduğu söylenebilir. 1874 yılında ise yeni bir nizamname oluşturularak eski eserlerin artık devlet malı olduğu hükmü getirilmiştir. $\mathrm{Bu}$ hüküm günümüze kadar oluşturulan tüm mevzuatlarda kalıcı olarak yer almıştır (Akat, 1990: 14). Tarihi eserlerin içerisinde yer aldığ varlıklarının korunmasında en son hazırlanan temel kanun ise 2863 sayılı Kültür ve Tabiat Varlıkları Koruma Kanunu'dur (At1lgan, 2016). Bu kanunda taşınır ve taşınmaz kültür varlıklarının korunmasıyla ilgili kararlar yer almaktadır. Kültür varlıklarının tanımı, 2863 sayılı Kültür ve Tabiat Varlıkları Koruma Kanunu'nun 3. maddesinin ' $a$ ' bendinin 1. alt bendinde: "Kültür varlıklarl; tarih öncesi ve tarihi devirlere ait bilim, kültür, din ve güzel sanatlarla ilgili bulunan veya tarih öncesi ya da tarihi devirlerde sosyal yaşama konu olmuş bilimsel ve kültürel açıdan özgün değer taşıyan yer üstünde, yer altında veya su altındaki bütün taşınır ve taşınmaz varlıklardır." şeklinde tanımlanmıştır (Kültür ve Tabiat Varlıklarını Koruma Kanunu, 1983). Kanunun 2. bölümünün $\mathrm{d}$ bendinde, korunması zorunlu taşınmaz kültür varlıklarının içerisinde "ören yeri" ifadesi de yer almaktadır. Ören yeri ise, 2863 say1lı Kültür ve Tabiat Varlıkları Koruma Kanunu'nun 3. maddesinin 'a' bendinin 7. alt bendinde; "Ören yeri; tarih öncesinden günümüze kadar gelen çeşitli uygarlıkların ürünü olup, topoğrafik olarak tanımlanabilecek derecede yeterince belirgin ve mütecanis özelliklere sahip, aynı zamanda tarihsel, arkeolojik, sanatsal, bilimsel, sosyal veya teknik bakımlardan dikkate değer, kısmen inşa edilmiş, insan emeği kültür varlıklar ile tabiat varlıklarının birleştiği alanlardır." şeklinde tanımlanmıştır (Kültür ve Tabiat Varlıklarını Koruma Kanunu, 1983). 
Ören yerlerinin korunması ile ilgili birden fazla mevzuat bulunmaktadır. Bunlardan bir tanesi Müzeler İç Hizmet Yönetmeliği'dir. Kültür ve Turizm Bakanlığı Teftiş Kurulu Başkanlığı'nın Müzeler İç Hizmet Yönetmeliği'nin 5. maddesinin e bendinde 2863 sayılı kanunun içerdiği tüm taşınmaz kültür varlıklarının korumasının müzelerin sorumluluğunda olduğu belirtilmiştir (Kültür ve Turizm Bakanlığ1, 1990). Ören yerlerinin korunması kapsamında hazırlanan bir diğer düzenleme ise Müzecilik Kılavuzu'dur. Kültür ve Turizm Bakanlığı Teftiş Kurulu Başkanlığı'nın yayınladığı Müzecilik Kılavuzu'nda kılavuzun amaçlarından bir tanesinin "müzelerde ve ören yerlerinde yer alan taşınır ve taşınmaz kültür ve tabiat varlıklarının her türlü tehlikeye karşı korunması ve bunun için tüm imkanları kullanarak gerekli önlemlerin alınmasını sağlamaktır." olduğu belirtilmiştir. Ayrıca yine aynı kılavuzun içerisinde kapsam bölümünde " $\mathrm{Bu}$ kılavuz müze ve ören yerlerindeki güvenlik önlemlerinin nasıl ve ne şekilde alınması gerektiğini kapsar." ifadesi yer almaktadır (Kültür ve Turizm Bakanlığ1, 2001). Bu ifadelerden hareketle müzeler için çıkartılan kılavuzun aynı zamanda ören yerlerinin korunması için de çıkartıldığı anlaşılmaktadır.

Mevzuatlara rağmen Türkiye içerisinde kaçak kazıların halen devam ettiği bilinmektedir. Kaçak kazılarla ilgili müdahale yetkisi olan kurumlardan bir tanesi, Emniyet Genel Müdürlüğü Kaçakçllık ve Organize Suçlarla Mücadele Daire Başkanlığı'dır. Kaçakçılık ve Organize Suçlarla Mücadele Daire Başkanlığı'nın yayınladığı 2018 raporuna göre, tarihi eser kaçakçıllğ 1 ile mücadelede, 2018 yılinda toplam 604 adet operasyon gerçekleştirilmiş, bu operasyonlar neticesinde 1.251 şüpheli hakkında yasal işlem yapılmıştır. Geçen yıla oranla olay sayısında \%21 ve şüpheli sayısında $\% 25$ artış olduğu görülmüştür. $\mathrm{Bu}$ artışların çok sayıda planlı çalışmanın operasyonel faaliyetlere dönüştürülmesinin yanı sıra tarihi eserlerin satışı noktasında en etkin konumda olan koleksiyoner ve antikacılara yönelik başarılı operasyonlardan kaynaklandığ 1 değerlendirilmektedir (Emniyet Genel Müdürlüğü Kaçakçılık ve Organize Suçlarla Mücadele Daire Başkanlığı, 2019)

Tarihi eser olaylarının en çok meydana geldiği şehirlere göz atıldığında suça karışan antikacı ve koleksiyonerlerin yoğun bulunduğu büyük ölçekli şehirler, yurt dışı çıkış noktaları bulunan liman şehirleri ve eski eser kaçakçılığı açısından potansiyel risk taşıyan şehirlerin ağırlık kazandığı görülmektedir. 2018'de gerçekleştirilen operasyonlarda, tarihi eser kaçakçıllı̆ı olayları eylem tipine göre ele alındığında; taşınır kültür varlıklarının \% 20' sinin kaçak kazılar sırasında ele geçirildiği anlaşılmıştır. 2018 yılında Türkiye genelinde gerçekleştirilen operasyonlar içerisinde 50 adet dedektör ve 4 alan tarama cihazının ele geçtiği not düşülmüştür. Ele geçirilen dedektörlerin diğer senelere göre sayısının artmasının en büyük sebeplerinden birisi, internette verilen dedektör reklamları olduğu düşünülmektedir (Emniyet Genel Müdürlüğü Kaçakçılık ve Organize Suçlarla Mücadele Daire Başkanlığı, 2019)

$\mathrm{Bu}$ araştırmanın yapıldığı yer olan Aydın ili ise geçmişten bu yana kültür varlıklarını yağmalayarak yurtdışına kaçırmaya çalışan devletlerin sürekli hedefi olmuştur. Osmanlı Devleti'nin son yıllarına doğru Anadolu içerisinde bulunan birçok eser tahrip edilmiştir. Türkiye'nin ilk demiryolu İngilizler tarafından $1857^{\prime}$ de başlatılıp 1866'da inşası biten İzmir- Aydın demiryoludur. $\mathrm{Bu}$ demiryolunun güzergâhında ve yakın civarında "Efes Antik Kenti, Metropolis, Magnesia, Nysa, Myus, Miletos, Priene, Tralleis" gibi antik kentler yer almaktadır. Demiryolunun yapılması bölgenin yağmalanmasını daha da kolaylaştırmıştır (Deniz 2000'den aktaran Akkuş 2009: 40).

Günümüzde tüm bu kanunlara ve mevzuatlara rağmen ülke genelinde tarihi eser kaçakçılığının ve eser tahribatının hala daha devam ettiği bilinmektedir. Kaçakçılık ve Organize Suçlarla Mücadele Daire Başkanlığı'nın yayınladığı rapora göre 2018 y1lında Türkiye genelinde toplamda 70.372 adet eser ve sikke, çeşitli operasyonlarla ele geçirilmiştir. 2018 y1lında en fazla kültür ve tabiat varlıkları kaçakçılığı olayı olan ilk 20 ilin içerisinde Aydın ili 5. Sıradadır ve toplamda 26 adet kaçakçılık vakası yaşandığı tespit edilmiştir. Aydın ili içerisinde yapılan operasyonlarda toplamda 1.154 tarihi eser ele geçirilmiştir. En çok tarihi eser ele geçirilen iller arasında Aydın ili 9. sıradadır (Emniyet Genel Müdürlüğü Kaçakçılık ve Organize Suçlarla Mücadele Daire Başkanlığı, 2019). Aydın ilinde yaşanan bir kaçak kazıya dair 21 Kasım tarihinde yayınlanan gazete haberinde, 
gece saatlerinde UNESCO dünya mirası listesinde olan Afrodisias Antik Kenti'nin bulunduğu Geyre Mahallesi'ndeki İsmet Y1lmaz'a ait zeytinlik arazide kaçak kazı yapan 5- 6 kişilik bir grup olduğundan bahsedilmiştir. İhbar üzerine bölgeye giden ekipleri fark eden grupların kaçtığı ve bu operasyon sonucunda kaçak kazı yapılan arazinin altında 2.500 y1llık bir lahit keşfedildiği belirtilmiştir (Sabah, 2019).

Türkiye genelinde birçok ören yeri henüz kamulaştırılmadığı için korunma altına alınamadığ bilinmektedir. Kültür ve Turizm Bakanlığg'nın hazırladığı 2863 sayılı Kültür ve Tabiat Varlıklarını Koruma Kanunu'nun 15. maddesinin a bendinde, kamulaştırma faaliyetlerine karar verilmesinde rol oynayan kurumun Kültür ve Turizm Bakanlığı olduğu; "Kısmen veya tamamen gerçek ve tüzelkişilerle mülkiyetine geçmiş olan korunması gerekli taşınmaz kültür ve tabiat varlıkları ile korunma alanları Kültür ve Turizm Bakanlığınca hazırlanacak programlara uygun olarak kamulaştırllır. Bu maksat için, Kültür ve Turizm Bakanlı̆̆ bütçesine yeterli ödenek konur" şeklinde belirtilmiştir. $\mathrm{Bu}$ kanunun $\mathrm{c}$ bendinde kamulaştırma faaliyetlerinde yetkili diğer kurum ve kuruluşların da olduğu şu şekilde belirtilmiştir; "Korunması gerekli taşınmaz kültür ve tabiat varlıklarınin korunma alanları, imar planinda yola, otoparka, yeşil sahaya rastliyorsa bunların belediyelerce; sair kamu kurum ve kuruluşlarının bakım ve onarım ile görevli olduklart veya kullandıkları bu gibi kültür varlıklarının korunma olanlarının ise, bu kurum ve kuruluşlarca, kamulaştırılması esastır." (Kültür ve Tabiat Varlıklarını Koruma Kanunu, 1983). Ayrıca Türkiye'de ören yerlerinin yer aldığ 1 arazilerin birçoğunun hem kamuya hem de şahıslara ait olduğu bilinmektedir. Özel'e (2005) göre Türkiye'de bulunan taşınmaz kültür varlıklarının tamamı devlete ait değildir. Şahıslara ait mülkiyetler üzerinde yer alan taşınmaz kültür varlıkları da vardır ve şahısların bu mülkiyet üzerindeki kullanım hakları da kısıtlandırılmıştır. Fakat bu kisitlandırmaların, mülkiyetin hak sahipliğinin hukuken tamamılla kamuya verildiği söylenemez.

Berkok'a (1991) göre Türkiye'deki kaçak kazıların ortaya çıkmasının önemli sorunlardan bir tanesi devletin Kültür ve Turizm Bakanlığı'na ayırdığı ödeneğin yetersiz olmasıdır. Bundan ötürü ören yerlerinin üzerinde bulunduğu arazilerin tamamının kamulaştırılmaması mümkün olmamaktadır. Mali sorunlardan dolayı birçok eserin yer aldığ 1 bölgelerde kaçak kazılar engellenememektedir.

Basına yansıyan bir başka haberde Aydın'ın Tralleis Antik Kenti'ne gece saat 21.00 siralarında gizlice giren kaçakçıların eserleri kaçırdığı belirtilmiştir. Yıllardır kazı çalışmaları devam eden Aydın ilindeki Tralleis Antik Kenti'nin etrafinın tel örgü ve güvenlik sistemleri ile çevrelenmesine rağmen hırsızların veya kaçakçıların kazı deposuna çatıya yakın bölgeden girerek tarihi eserleri kaçırdıkları ve bulunamadıkları ifade edilmiştir (İhlas Haber Ajans1, 2017). Kültür varlıklarının kaçakçılığının önlenmesini engelleyen sorunlar Akkuş'a (2009: 144) göre şu şekilde belirtilmektedir;

- Kurumlar arasi koordinasyon problemleri,

- Suçların önlenmesine dair toplumda yer alan bireylerin yeterli düzeyde bilince sahip olmamas1,

- Tarihi eser kaçakçılığının önlenmesi için kitle iletişim araçlarının fonksiyonlarının yetersiz kalmas1,

- Para ve hapis gibi yaptırımların yeterince caydirıc1 olmamasi ve bu yaptırımların uygulanmasina dair mevzuatta ve kanunlarda yetersizlik olmas1,

- İhbar edenlere verilen ikramiyelerin teşvik edici düzeyde olmamas1,

- Koleksiyonerler ile ilgili mevzuat eksiklikleri ve denetimlerin yeterli seviyede olmamas1,

- Define aranmasına hakkındaki işlemlerde mevzuattaki belirtilenlerin dışında bir sürecin ilerlemesi,

- Mali açıdan kaynaklanan yetersizlikler.

Kültürel mirasın korunması sadece devletler için değil, uluslararası hukukta kanıtlandığı gibi kültürel mirasın korunmasına yönelik hak ve yükümlülükleri olan bireyler için de geçerli olan çok boyutlu bir konudur. Bireylerin ve grupların kültürel miraslarının korunmasında aktif rolü vardır (Papaioannou, 2017). Aladağ (2010: 139140) tarafindan gerçekleştirilen başka bir çalışmada, kültür varlıklarının korunmasında Türkiye'nin hazırladığı kanun ve mevzuatların ve bu mevzuatlarda yetkilendirilen kişilerin yetersiz kaldığına dikkat çekilmektedir. Kurum ve kuruluşların sayısının çoğalmasının olayların 
çözülmesinde tam tersine yetki karmaşası oluşturduğu ve kültür varlıklarının korunması ve geliştirilmesinin bu gibi nedenlerden dolayı daha da zorlaştırıldığı ifade edilmektedir. Bu nedenle yetki ve sorumluluk dağılımının tekrar gözden geçirilmesi gerektiği belirtilmektedir. Son olarak Nesli'ye (2018) göre Kültür ve tabiat varlıklarının korunmasiyla ilgili mevzuatın kapsamlı olmasından dolayı, bir dağınıklık olduğu söz konusudur. Ayrıca çıkan sonuçlarda yönetmeliklerin birden fazla düzenlenmesinden kaynaklanan karışıklıklar olduğu tespit edilmiştir. Tüm bu yapılan araştırmalara ve haberlerden hareketle kanun ve mevzuatlar çerçevesinde bu çalışmada, Aydın ili sınırları içerisinde bulunan 8 adet ören yerinin korunmasına yönelik güvenlik önlemlerinin ne düzeyde alındığ incelenmektedir.

\section{YÖNTEM}

Aydın ili sınırları içerisinde yer alan ören yerlerinin güvenlik düzeylerini nitel bir yaklaşımla belirlemeye yönelik gerçekleştirilen bu araştırma verilerinin toplanmasında, gözlem yöntemine başvurulmuştur. Gözlem yöntemi, araştırmacılar tarafından farklı şekillerde sınıflandırılmaktadır. Söz gelimi Kozak (2014: 93-94) gözlemi, doğal ortamlarda gözlem ve yapay ortamlarda gözlem şeklinde sınıflandırırken Altunışık ve diğerleri (2010: 99-101) gözlemi, katılımsız (doğal gözlem, simülasyon- canlandırma) gözlem ve katılımlı gözlem olmak üzere iki kategoride ele almaktadır. Akturan ve diğerleri (2013: 100-102) tarafindan yapılan başka bir sınıflandırmaya göre ise gözlem; katılımlı, katılımsız ve mekanik gözlem olmak üzere üç kategoride incelenmektedir. Yapılan bu sınıflandırmalardan hareketle gerçekleştirilen bu araştırmada, veri toplama yöntemi olarak doğal gözlemden (katılımsız) yararlanılmıştır. Araştırmada doğal gözleme başvurulmasında, ören yerlerindeki güvenlik sorunlarını, objektif bir gözle değerlendirme amacı etkili olmuştur. Araştırmanın gerçekleştirildiği bölgenin (Aydın ili) seçiminde ise;

- Döner Sermaye İşletmesi Merkez Müdürlügü’nün hazırladığg 1 Türkiye'de en çok ziyaret edilen antik kentler siralamasına göre, 204.770 ziyaretçi ile Aydın ilinin 9. surada yer alması (Kültür ve Turizm Bakanlığı, 2019b),

- Kültür ve Turizm Bakanlığı Yatırım ve İşletmeler Genel Müdürlügü̈’nün 2018 yıl1 Turizm İstatistikleri genel değerlendirme raporuna göre, 6,5 milyon yerli ve yabanc1 turist ile Aydın ilinin en fazla konaklanılan dördüncü şehir olması (Kültür ve Turizm Bakanlığı, 2019a),

- 2018 y1lı Kaçakçılık ve Organize Suçlarla Mücadele Raporu'na göre, en fazla kültür ve tabiat varlıkları kaçakçılığı olan 20 il arasında Aydın ilinin 5. sırada yer alması (Emniyet Genel Müdürlüğü Kaçakçıllk ve Organize Suçlarla Mücadele Daire Başkanlığı, 2019) etkili olmuştur.

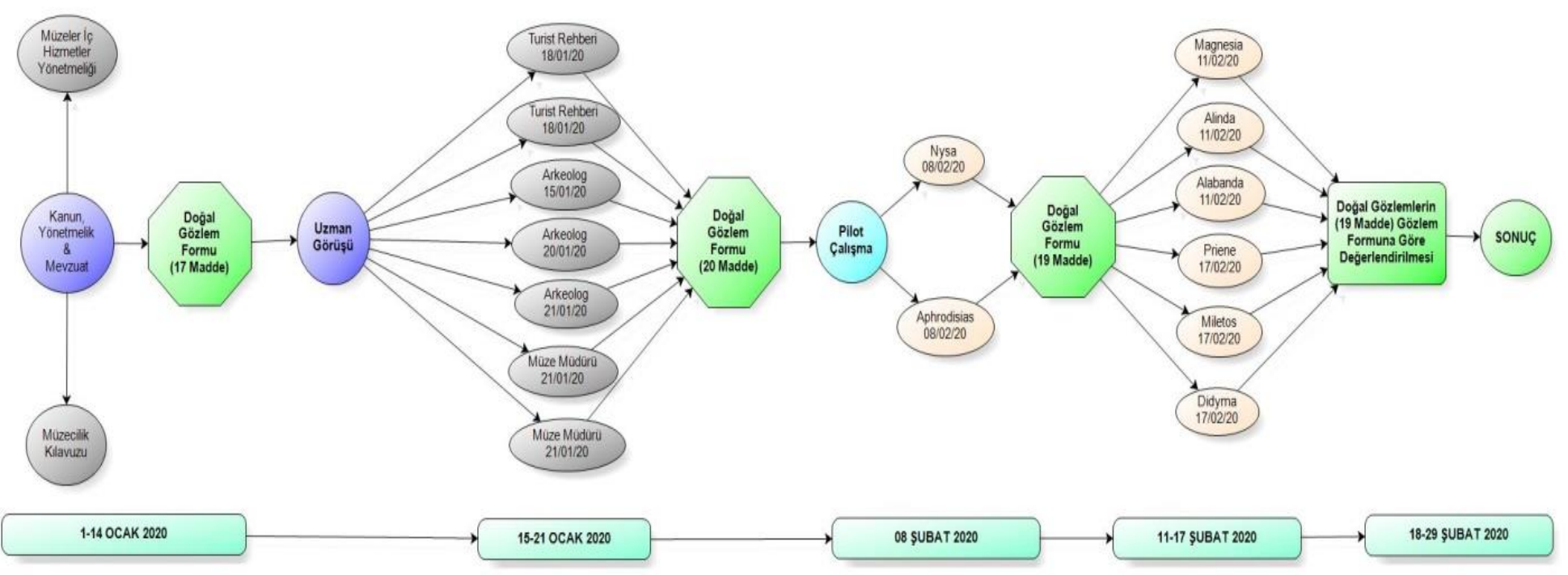

Şekil 1: Araştırma Süreci 
Araştırmada öncelikle, Kültür ve Turizm Bakanlığı'na bağlı Teftiş Kurulu Başkanlığı'nın 2863 Sayılı Kültür ve Tabiat Varlıklarını Koruma Kanunu mevzuatı, Kültür ve Turizm Bakanlığ Yatırım ve İşletmeler Genel Müdürlügü'nün ve Türkiye Cumhuriyeti İçişleri Bakanlığı Emniyet Genel Müdürlüğü Kaçakçılık ve Organize Suçlarla Mücadele Daire Başkanlığı'nın 2018 yılında hazırlanılan raporları incelenmiş ve bu bilgilerden hareketle 17 maddeden oluşan bir gözlem formu oluşturulmuştur. Gözlem formunda yer alan ifadelerin geçerliliğini belirlemek üzere, 15-21 Ocak 2020 tarihleri arasında, 3 arkeolog, Kültür ve Turizm Bakanlığı'na bağlı müzelerde görev yapmış 2 müze müdürü ile 25 yıl ve üzeri sektör deneyimine sahip 2 profesyonel turist rehberinden oluşan toplamda $\mathbf{7}$ uzman görüşüne başvurulmuştur (Şekil 1).

$\mathrm{Bu}$ görüşmeler neticesinde, gözlem maddelerinin içeriği ve sıralamasında düzenlemeye gidilmiş ve gözlem formuna son şekli verilmiştir. Oluşturulan bu gözlem formunu test edebilmek amaciyla, 08.02.2020 tarihinde Afrodisias ve Nysa ören yerleri hem gündüz saatlerinde hem de akşam saatlerinde ziyaret edilmiştir. Ön testte, toplamda 2 saat 35 dakika gözlem gerçekleştirilmiştir. Karasar (2009: 161), tek bir gözlemci tarafindan gerçekleştirilen gözlemlerin güvenirliliğini kestirmenin zor olduğunu belirterek araştırmalarda en az iki gözlemcinin yer alması gerektiğine işaret etmektedir. $\mathrm{Bu}$ noktadan hareketle gözlemler esnasında, herhangi bir detayın göz ard1 edilmemesi adina profesyonel turist rehberi olan birinci yazar ile birlikte başka bir gözlemci (profesyonel turist rehberi) daha görev almıştır. Gözlemlere başlamadan önce, bir gözlem defteri oluşturulmuş ve ören yeri ziyaretleri esnasında gözlenebilen her şey bu gözlem defterine not edilmiştir. Örneğin:

“... 11.02.2020... 15.45. Ören yeri bölgesinde antik kentin adının bulunduğu levhanın ve Araphisar Mahallesi levhasının olduğu yerden sol tarafa dönerek Tiyatro yapısina doğru geçiş yaptıktan sonra aracımızı üniformalı güvenlik görevlisinin bize baktığl tek katlı binanın yanına park ettik. Daha sonra güvenlik görevlisinin ve bir kişinin daha bulunduğu binaya doğru yürüdüğ̈̈müzde, kendilerine ören yerini ziyaret edeceğimizi bildirdik. Ardindan araca tekrar bindik. Köy içerisinde bulunan evler arasından geçiş yaparak son nokta olan Tiyatro yapısının girişine vararak park ettik..."

Ön test sonrasında, iki gözlemci tarafindan da gözlemlenemeyen bir madde (Ören yerinde, herhangi bir haberleşme ağı (telsiz, mobil, internet) bulunmakta mıdır?) gözlem formundan çıkarılmasına karar verilmiştir (Ek-1). 19 maddelik nihai gözlem formu çerçevesinde Aydın ili sınırları içerisinde yer alan 6 ören yerinde (Magnesia, Alinda, Alabanda, Priene, Miletos, Didyma) gözlemler gerçekleştirilmiştir (Tablo-1).

Tablo 1: Ören yerleri Gözlem Süreleri

\begin{tabular}{|l|l|l|l|l|}
\hline \multirow{2}{*}{$\begin{array}{l}\text { GÖZLEM } \\
\text { TARİHI }\end{array}$} & \multirow{3}{*}{ GÖZLEM YERI } & $\begin{array}{l}\text { GÖZLEM } \\
\text { ARALIĞI }\end{array}$ & SAAT & \multirow{2}{*}{$\begin{array}{l}\text { TOPLAM } \\
\text { GÖZLEM SÜRESI }\end{array}$} \\
\cline { 3 - 5 } & & GÜNDÜZ & GECE & \\
\hline 08.02 .2020 & Nysa Ören Yeri & $14: 20-15: 20$ & $19: 05-19: 20$ & 1 saat 15 dakika \\
\hline 08.02 .2020 & Afrodisias Ören Yeri & $16: 35-18: 00$ & 1 saat 25 dakika \\
\hline 11.02 .2020 & Magnesia Ören Yeri & $13: 35-14: 50$ & $20: 50-21: 05$ & 1 saat 30 dakika \\
\hline 11.02 .2020 & Alabanda Ören Yeri & $15: 45-16: 46$ & $19: 31-19: 47$ & 1 saat 17 dakika \\
\hline 11.02 .2020 & Alinda Ören Yeri & $17: 14-19: 00$ & 1 saat 46 dakika \\
\hline 17.02 .2020 & Priene Ören Yeri & $12: 45-14: 00$ & $19: 39-19: 51$ & 1 saat 27 dakika \\
\hline 17.02 .2020 & Milet ören Yeri & $15: 09-16: 29$ & $18: 54-19: 24$ & 1 saat 50 dakika \\
\hline 17.02 .2020 & Didyma Ören Yeri & $16: 43-18: 37$ & 1 saat 54 dakika \\
\hline
\end{tabular}

6 ören yerinde gerçekleştirilen bu gözlemlerde, pilot çalışmada olduğu gibi profesyonel turist rehberi olan birinci yazarın yanı sıra başka bir gözlemci (profesyonel turist rehberi) daha görev 
almıştır. Araştırmaya dâhil edilen ören yerlerinin belirlenmesinde ise Döner Sermaye İşletmesi Merkez Müdürlügü̈nün hazırladığı "2018 Müze ve Ören Yeri Ziyaretçi İstatistikleri” etkili olmuştur (Kültür ve Turizm Bakanlığı, 2019b). Bu raporda, Aydın ili sınırları içerisinde yalnızca 8 ören yerinin turist gruplarının ziyaretlerine açık olduğu belirtilmektedir. Gözlemciler, aynı zamanda ören yerlerinin fotoğraflarını çekmiştir. Gözlem defterine yazılan notlar, ören yeri ziyareti sonrasında MS Word dosyasına aktarılmış, sonrasında ise 19 maddeden oluşan gözlem formu çerçevesinde bir bütün olarak değerlendirilmiştir. Araştırma süreci, Şekil-1'de sunulmaktadır.

\section{BULGULAR}

Bu bölümde, Aydın ili sınırları içerisinde yer alan ören yerlerinin güvenlik düzeylerini belirlemeye yönelik gerçekleştirilen doğal gözlemlere ilişkin sonuçlara yer verilmektedir.

\section{Ön Teste İlişkin Bulgular}

1- "Ören yeri koruma alanı muhafaza altına alınmış midır?"

Nysa ören yerinde her iki gözlemci tarafından gerçekleştirilen gözlemlerde, kazı çalışması gerçekleştirilen alan dışında, ören yerini çevreleyen herhangi bir koruma önleminin alınmadığı tespit edilmiştir. Ören yerine ilk giriş esnasında raylı bir kap1 sistemi olduğunu belirten 1 nolu gözlemci, Bu kapının hem gündüz saatlerinde hem de akşam mesai saati bitimi sonrasında araç girişine açık tutulduğunu gözlemlemiştir. Afrodisias ören yerinde gerçekleştirilen gözlemlerde ise, girişten itibaren Tetrapylon, Stadium, Afrodite Tapınağı, Odeon, Hadrian Hamamları, Güney Agora, Amfi Tiyatro, Tiyatro Hamamlar, Sebasteion güzergâhının tamamen tel örgü ile muhafaza altına alındığı not edilmiştir.

2- $\quad$ Ören yeri iç bölgesi (hinterlantı) içerisinde imar faaliyetleri yerleșim katmanlarını tehdit etmekte midir?

Her iki gözlemci hem Afrodisias hem de Nysa ören yeri iç bölgesi içerisinde yerleşim katmanını tehdit edebilecek herhangi bir imar faaliyetinin olmadığını not etmiştir.

3- Ören yerinde, güvenlik, bekçi veya koruma görevlisi var mıdır? Var ise sayısı kaçtır?

Nysa ören yerinde gerçekleştirilen gözlemlerde, ören yerinde görevli olan 1 adet güvenlik görevlisi haricinde herhangi bir görevlinin olmadığ her iki gözlemci tarafından not edilmiştir. Afrodisias kentinde gerçekleştirilen gözlemlerde ise ören yeri giriş turnikelerine ve gişe ofisine gelmeden sol tarafta yer alan Jandarma binasının önünde otoparkı izleyen silahlı bir Jandarma polisi olduğu, ören yeri girişinin akabinde Döner Sermaye İşletme Müdürlüğü altında çalışan bir adet gişe görevlisi tespit edilmiştir. Ancak ören yerinin giriş bölümünde yer alan müze dışında, herhangi bir yerde güvenlik görevlisinin olmadığı her iki gözlemci tarafindan kaydedilmiştir.

4- $\quad$ Ören yerinde güvenlik görevlisi var ise olası bir saldırıya ya da kaçak kazıya müdahale ederken kendilerini koruyabilecekleri herhangi bir savunma malzemesi (cop, silah vb.) bulundurmakta midir?

Nysa ören yeri girişinde görevli olan güvenlik görevlisinin üzerinde herhangi bir saldırı ya da kaçak kazı durumunda müdahalede bulunabileceği herhangi bir savunma malzemesi üzerinde bulundurmadığı gözlemlenmiştir. Gözlemcilerin, güvenlik kulübesine giriş sağlayamamaları nedeniyle kulübe içerisinde herhangi bir savunma malzemesinin bulunup bulunmadığ edilememiştir. Benzer şekilde Afrodisias'ta gerçekleştirilen gözlemlerde, müze kapısında yer alan güvenlik görevlisinin üzerinde herhangi bir savunma malzemesinin bulunup bulunmadiğ gözlemlenememiştir.

5- $\quad$ Ören yerinde, güvenlik personeline tahsis edilen herhangi bir ofis var midir?

Nysa ören yerinde gerçekleştirilen gözlemlerde hem bilet gişesi hem de güvenlik kulübesi olarak kullanılan tek bir ofisin bulunduğunu her iki gözlemci tarafından tespit edilirken Afrodisias'ta, ören yeri girişinde gişe ofisinin karşısında bir adet prefabrik ofis olduğu ancak bu yapının güvenlik görevlisine tahsis edilip edilmediği tam olarak anlaşılmamıştır.

6- $\quad$ Ören yerinde çalışan güvenlik personeline yönelik mesai saatleri dlşında herhangi bir vardiya sistemi uygulanmakta midır?

Saat 16.35 'te gözlemciler, Afrodisias kentine giriş sağladıklarında, ören yerine en son giriş saatinin 17.00 olduğu ve içeride bulunan ziyaretçilerin tahliye işleminin 17.30 'da gerçekleştirileceği bilgisi gözlemcilere iletilmiştir. Saat 17.30 'da gişe görevlisi tarafından verilen talimatı doğrultusunda gözlemciler, çıkışa yönelmiş ancak 15 dakika kadar müzenin karşısında gözlem yapmaya devam etmişlerdir. Tahliye uyarıları doğrultusunda saat 
18.00 'da gözlemcilerin, ören yeri bölgesinin terk etmek zorunda kalmaları nedeniyle herhangi bir güvenlik görevlisi ya da bekçinin akşam vardiyasında görev alıp almadığ1 gözlemlenememiştir. Ancak saat 19.05 'te mesai saati sonrasinda Nysa ören yeri yeniden ziyaret edildiğinde, girişte bulunan gişenin kapalı olduğu, araç ile ören yerine girildiğinde ise içeride herhangi bir güvenlik görevlisinin olmadığı her iki gözlemci tarafından not edilmiştir.

7- $\quad$ Ören yerinde, çevre izleme ve takip sistemi (kamera, drone vb.) kullanılmakta midır?

Nysa ören yerinde gerçekleştirilen gözlemlerde, güvenlik görevlisinin bulunduğu kulübenin önünde 2 adet kamera haricinde Agora, Meclis Binas1, Çarşı Bazilikası, Amfi Tiyatro, Kütüphane, Gymnasion gibi yapılarda herhangi bir çevre izleme ve takip sisteminin olmadığ gözlemci tarafindan not edilmiştir. Afrodisias ören yerinde gerçekleştirilen gözlemlerde ise ziyaret edilebilen bölgelerde 3'ü 360 derece dönebilen (Tetrapylon, Stadium ve Tiyatro), 10'u ise sabit olmak üzere toplam 13 adet güvenlik kameras1 tespit edilmiştir. Diğer yandan hem Nysa hem de Afrodisias'ta, gözlem süresince herhangi bir drone uçuşunun olmadığı not edilmiştir.

8- Ören yerindeki eserlerin korunmasina yönelik herhangi bir alarm sistemi var midır?

Nysa ören yerinde, gişe/ güvenlik kulübesinin alarm sistemi ile korunduğu ancak ören yeri içerisinde herhangi bir alarm sisteminin olmadiğ 1 gözlemlenmiştir. 1 nolu gözlemci, gözlemlenen alarm sisteminin, gişe/güvenlik kulübesinin arkasında bulunan kazı ekibine ait yapıları koruduğunu tespit etmiştir. Afrodisias'ta ise, müze binası dışında hiçbir bölgede alarm sisteminin olmadığı her iki gözlemci tarafindan kaydedilmiştir.

9- $\quad$ Ören yerinde, herhangi bir haberleşme ăg (telsiz, mobil, internet) bulunmakta midır?

Hem Nysa hem de Afrodisias ören yerinde gerçekleştirilen gözlemlerde, ören yeri içerisinde herhangi bir haberleşme ağının olup olmadığı, her iki gözlemci tarafından da gözlemlenememiştir.

10- Ören yerinde kazl faaliyetlerinin sürdürülmesi ve güvenliğin sağlanması amactyla elektrik verilmekte midir?

Nysa ören yeri içerisinde elektrik direklerinin olduğu, her iki gözlemci tarafindan not edilmiştir. 1 nolu gözlemci, ören yeri içerisinden geçen yolda bulunan bir elektrik direğine monte edilmiş, üzerinde "İl Kültür ve Turizm Müdürlüğü" ibaresi bulunan bir elektrik panosu gözlemlemiştir. Afrodisias ören yerinde ise, bütün kameraların altında elektrik kablolarının olduğu ve bazı kamera direklerinde elektrik panosu ile priz takılabilecek bölümlerin olduğu her iki gözlemci tarafından not edilmiştir.

11- Ören yerinde aydinlatma sistemi var midır? Varsa ne düzeydedir?

Nysa'da, gündüz vakti (14.20-15.20 aras1) tiyatronun sağ ve sol giriş kapılarının bitişiğinde, yere monte edilmiş bir aydınlatma düzeneği bulunmasına rağmen ören yerindeki diğer yapılarda herhangi bir aydınlatmanın olmadığı her iki gözlemci tarafından not edilmiştir. Akşam saatlerinde (19.05'te) yeniden ziyaret edildiğinde, tiyatro girişinde bulunan 1şıkların çalışmadığ ancak Kavaklı Köyü'ne giden yolun üstünde bulunan sokak lambalarının ören yerini bir miktar aydınlattığı her iki gözlemci tarafından kaydedilmiştir. Afrodisias'taki gözlemlerde ise, Tetrapylon- Stadium- Aphrodite Tapınağ1- OdeonHadrian Hamamlar1- Güney Agora- Amfi TiyatroTiyatro Hamamları- Sebasteion güzergâhında birçok aydınlatma direğinin bulunduğu her iki gözlemci tarafindan not edilmiştir.

12- Ören yerinde olast elektrik kesintisinde kullanilabilecek herhangi bir teçhizat (jeneratör gibi) var midır?

Nysa ören yerinde, olası bir elektrik kesintisinde devreye girebilecek herhangi bir teçhizatın olmadığı her iki gözlemci tarafindan tespit edilirken Afrodisias'ta, gişe ofisi olarak kullanılan yapının arkasında bir adet jeneratör tespit edilmiştir.

13- Ören yerini ziyaret edenlerin paket ve çantalarl, herhangi bir kontrolden (x-ray cihazı, el dedektörü, $x$-ray metal kapı dedektörleri gibi) geçmekte midir?

Hem Nysa hem de Afrodisias ören yeri girişinde, x-ray, el dedektörü, x-ray metal kapı dedektörü gibi herhangi bir güvenlik tarama aracının kullanılmadığı her iki gözlemci tarafindan not edilmiştir.

14- Ören yerinde sabotaj, yangın, hirsızlık $v b$. durumlara yönelik herhangi bir önlem alınmış midir?

Nysa ören yerinde, sabotaj ve yangın durumuna yönelik alınan herhangi bir önlemin alınmadığ gibi yakınlarda bulunan şahsi arazilerden ören yerine girişin kolaylıkla sağlanabilmesi nedeniyle 
olası hırsızlık durumuna karşı herhangi bir güvenlik tedbirinin olmadığı her iki gözlemci tarafından not edilmiştir. Afrodisias ören yerinde gerçekleştirilen gözlemlerde ise, müzenin eski kafeteryası ile yeni kafeteryası arasinda bir adet yangın dolabı her iki gözlemci tarafından kaydedilmiştir.

15- Ören yerinde üzerine basılan ve koruma altına alınmamıs herhangi bir eser var mıdır?

Hem Nysa hem de Afrodisias'ta, üzerine basılan ve koruma altına alınmamış herhangi bir esere rastlanmamıştır. Ancak Afrodisias müzesi bahçesinde yer alan lahit mezarların tam olarak koruma altına alınmadığı her iki gözlemci tarafindan not edilmiştir.

16- Ören yeri içerisinde girilmesi yasak olan yerlere yönelik herhangi bir uyart levhast konulmus mudur? Var ise bu uyarlar, hangi dillerde yazllmıştır?

Nysa ören yeri koruma alanı içerisinde toplam 3 farklı noktada tel örgülere asılı bulunan üzerinde Türkçe, Almanca ve İngilizce dillerinde "Dikkat! Kazı sahasına girmek tehlikelidir" yazılı uyarı levhaları her iki gözlemci tarafından tespit edilmiştir. Diğer yandan orijinalleri Aydın Müzesi'nde olduğu bilinen amfi tiyatrodaki kabartmaların etrafinın demir parmaklıklarla çevrili olduğu ancak herhangi bir uyarı levhasının bulunmadığı, 1 nolu gözlemci tarafından kaydedilmiştir. Afrodisias'ta, girilmesi yasak olduğu belirtilen alanların, kazı gerçekleştirilen alanlar olduğu her iki gözlemci tarafindan tespit edilmiştir. Üzerinde Türkçe ve İngilizce "Çalışma sahasıdır, Lütfen girmeyiniz! Work Area, Please Do not Enter!" yazılı 4 adet uyarı levhası tespit eden 1 nolu gözlemci, Hadrian Hamamları'ndaki kazı alanına girilmesini engellemek amaciyla tel örgü kullanıldığını ancak bu alanda herhangi bir uyarı levhası olmadığını not etmiştir.

17- Ören yerinde dokunulması yasak olan eserlere yönelik herhangi bir uyarl levhası konulmuş mudur? Var ise bu uyarlar, hangi dillerde yazllmıştır?

Hem Nysa hem de Afrodisias'ta, üzerinde dokunulması yasak olduğu belirtilen herhangi bir esere rastlanmadığı her iki gözlemci tarafından tespit edilmiştir.

18- Ören yeri içerisinde girilmesi yasak olan yerlere giren herhangi bir ziyaretçi var midır? Var ise bu ziyaretçilere gerekli müdahalede bulunulmuş mudur?
Nysa ören yerinde gerçekleştirilen gözlemlerde, girilmesi yasak olan yerlere girmeye teşebbüs eden herhangi bir ziyaretçi gözlemlenmemiştir. 1 nolu gözlemci, amfi tiyatro ziyareti esnasinda 8 ziyaretçinin tiyatroda olduğunu ancak tiyatro sahnesinde yer alan demir parmaklıkların ardına girmeye teşebbüs eden herhangi bir ziyaretçi olmadığını not etmiştir. Benzer şekilde Afrodisias ören yerinde gerçekleştirilen gözlemlerde, girilmesi yasak olduğu belirtilen yerlere girmeye teşebbüs eden herhangi bir ziyaretçi olmadığı her iki gözlemci tarafindan kaydedilmiştir. 1 nolu gözlemci, söz konusu gözlemleri esnasında, ören yerinde 4 kişilik ve 7 kişilik 2 ayrı turist grubunun ören yeri ziyareti gerçekleştirdiğini ancak bu turist gruplarından yasak olduğu belirtilen alanlara yönelen herhangi bir ziyaretçi olmadığını tespit etmiştir.

19- Ören yerinde dokunulmast yasak olan eserlere dokunan herhangi bir ziyaretçi var midır? Var ise bu ziyaretçilere, gerekli müdahalede bulunulmuş mudur?

Hem Nysa hem de Afrodisias'ta, üzerinde dokunulması yasak olduğu belirtilen herhangi bir esere rastlanmadığ 1 her iki gözlemci tarafindan not edilmiştir.

20- $\quad$ Ören yeri ziyareti esnasinda sigara içmeye yönelen herhangi bir ziyaretçi var mıdır? Var ise bu ziyaretçiye herhangi bir müdahalede bulunulmuş mudur?

Her iki gözlemci, Nysa ören yerinde gerçekleştirilen gözlemler esnasında sigara içmeye teşebbüs eden herhangi bir ziyaretçi ile karşılaşmamasına rağmen ören yerinin farklı noktalarda sigara izmaritlerine rastlamışlardır. Benzer şekilde Afrodisias'ta, sigara içmeye yönelen herhangi bir ziyaretçi gözlemlenmezken 1 nolu gözlemci, Meclis binasinın üst basamaklarından birinde 1 adet sigara izmariti tespit etmiştir.

\section{Ana Çalışma Bulguları}

1- "Ören yeri koruma alanı muhafaza altına alınmış midır?"

Yapılan gözlemler neticesinde, tamamı tel örgü ile koruma altına alındığı tek ören yerinin Didyma Apollon Tapınağı olduğu her iki gözlemci tarafından kaydedilmiştir. Ancak tel örgüler 
arasında bulunan boşluklar nedeniyle tapınağın bitişiğindeki bulunan konaklama işletmesi gibi tel örgü olmayan yerlerden içeriye insanların rahatlıkla girebilecekleri, söz gelimi tel örgüler arasında boşluk bulunan bir duvarın üstünde bir kız çocuğu ile bir erkek ziyaretçinin oturmakta olduğu 1 nolu gözlemci tarafindan not edilmiştir. Magnesia'da ise, Hypokaustlu Yapı'nın bir çatı ve tel örgü ile muhafaza altına alındığı, kazı çalışmaları devam eden Devlet Agorası, Kütüphane ve Latrina bölümlerinin etrafinın tel örgüyle çevrelendiği ancak Lethaios Gymnasion'u ile Stadium'daki podyum kabartmalarının bulunduğu kısmın haricinde ve Tiyatro'da, herhangi bir koruma sisteminin olmadığ 1 nolu gözlemci tarafından kaydedilmiştir. Diğer yandan Alinda'da, etrafi tel örgü ile çevrili bulunan tek yapının güvenlik personeline tahsis edilen ofis olduğu; Alabanda'da, Tiyatro, Apollon İsotimos Tapınağı ve Agora gibi kazı çalışması devam ettiği anlaşılan bölümlerde bir tel örgünün bulunmas1 dışında muhafaza altına alınan herhangi bir bölgenin olmadığ 1 her iki gözlemci tarafından not edilmiştir. Benzer şekilde Miletos'ta, tel örgü ile çevrili bulunan tek bölgenin İlyas Bey Külliyesi olduğu 1 nolu gözlemci tarafından kaydedilirken Priene'de Misır Tanrıları Alanı isimli bölgede bulunan uçurumun bulunduğu mevkide tahribata uğramış bir tel örgü 2 nolu gözlemci tarafından tespit edilmiştir.

2- $\quad$ Ören yeri iç bölgesi (hinterlantı) içerisinde imar faaliyetleri yerlessim katmanların tehdit etmekte midir?

2 ören yerinde (Alinda, Alabanda), yerleşim alanının yakınında modern yerleşime rastlanmıştır. Alinda'da, akropol alanının alt kısminda Karpuzlu Mahallesi'ndeki evlerin Agora yapısına yakın mesafede olduğu; Alabanda'da ise tiyatronun sol tarafinda yer alan eski evlerin tiyatro ile bitişik nizamda yer aldığı ve yaşayanların küçükbaş, büyükbaş hayvanları bahçesinde beslediği 1 nolu gözlemci tarafından not edilmiştir. Bunun yanı sıra Didyma'da, ören yerini çevreleyen yolun üzerinde yerleşim yerlerinin olduğu belirlenirken Miletos tarafindan gelen ve tapınağa çıkan Kutsal Yol üzerinde modern yerleşim tespit edilmiştir. Magnesia'da ise ören yerini tehdit edebilecek herhangi bir yapılaşma not edilmezken tel örgüyle çevrelenen alan ile Lethaios Gymnasium'u arasında aktif olarak kullanılan bir demir yolu (İzmir_Aydın Söke) tespit edilmiştir. Diğer yandan
2 ören yerinde (Miletos, Priene) ise ören yeri iç bölgesinde yerleşim katmanlarını tehdit edebilecek herhangi bir yapılaşmaya rastlanmamıştır.

3- $\quad$ Ören yerinde, güvenlik, bekçi veya koruma görevlisi var mıdır? Var ise sayısı kaçtır?

Alinda'da, 17.14'te, bir temizlik görevlisi ile üniformasız bir güvenlik görevlisi; Alabanda'da, üzerinde üniforma giyen bir güvenlik görevlisi ile yetkililere tahsis edilen bahçede duran ve boynunda yaka kartı bulunduran bir bekçi her iki gözlemci tarafından not edilmiştir. Miletos'ta yapılan gözlemlerde, DÖSIMM yaka kartı taşıyan 3 adet personelin ören yeri girişinde olduğu, bunların dışında herhangi bir bekçi ya da güvenlik görevlisi olmadığı her iki gözlemci tarafından kaydedilmiştir. Nitekim 1 nolu gözlemci, ören yerinden çıtıkları esnada müzeden çıkarak ören yerini kontrol etmeye yönelen 1 adet güvenlik görevlisi tespit etmiştir. Priene'de yapılan gözlemlerde, ören yeri girişinde yalnızca 1 adet güvenlik görevlisi olduğu her iki gözlemci tarafından not edilmiştir. Didyma'da ise, gişe ofisinde 2 adet ve müze kafeteryasinda 3 adet DÖSIMMM yaka kartlı personel gözlemlenirken saat 17.47 'de, ören yerinden çıkış yapıldığı esnada hiçbir yerde güvenlik görevlisi olmadığ 1 , vardiyaya yeni başlayacak olan ören yeri bekçinin kapıya yönelerek "neden bana haber vermeden mesaisini bitirip gitti bu güvenlik" şeklinde tepki gösterdiği 1 nolu gözlemci tarafından kaydedilmiştir. Gözlemciler ören yerini terk ettiklerinde, güvenlik görevlisinin içeride kalan ziyaretçileri tek tek uyararak dışarı çıkardığı; saat 18.13 'te, bekçinin ören yeri kapısını zincirle kilitlemesinin ardından hala içeride 2 ziyaretçinin bulunduğu, bekçinin düdüğüyle birlikte bu ziyaretçilerin de ören yerini terk ettiği; sonrasında ise bekçinin giriş kapısını içeriden kilitleyerek merdivenlerin bitiminde bulunan güvenlik kulübesine yöneldiği 1 nolu gözlemci tarafindan tespit edilmiştir. Diğer yandan Magnesia'da yapılan gözlemlerde, iki şahsın ören yeri girişinde bulunmasına rağmen herhangi bir üniforma giymemeleri nedeniyle güvenlik görevlisi olup olmadıkları tam olarak anlaşılamamıştır.

4- $\quad$ Ören yerinde güvenlik görevlisi var ise olası bir saldırıya ya da kaçak kazıya müdahale ederken kendilerini koruyabilecekleri herhangi bir savunma malzemesi (cop, silah vb.) bulundurmakta midir?

6 ören yerinin 4'ünde (Magnesia, Alinda, Miletos, Priene) gözlemlenen bekçi/ güvenlik görevlilerinin 
üzerinde, olası bir saldırı ya da kaçak kazıya müdahale ederken kendilerini koruyabilecekleri herhangi bir savunma malzemesi olmadığ gözlemci tarafindan not edilmiştir. Ancak Alabanda'da yapılan gözlemlerde, güvenlik görevlisinin üzerinde herhangi bir savunma malzemesi tespit edilmezken yetkililere ait ofisin bulunduğu bahçedeki bekçinin üzerinde bir adet silah her iki gözlemci tarafından kaydedilmiştir. Diğer yandan Didyma'da görevli bekçinin giydiği kıyafetin kalın olması nedeniyle herhangi bir savunma malzemesi bulundurup bulundurmadığ gözlemlenememiştir.

5- $\quad$ Ören yerinde, güvenlik personeline tahsis edilen herhangi bir ofis var midır?

Didyma'da, ören yeri girişinde merdivenlerin bitiminde sol alt bölmede güvenlik görevlilerine tahsis edilen prefabrik bir ofis; Magnesia'da, ziyaretçilerin kullanımına açık tuvalet bölümü bulunan bir yap1; Alabanda'da içerisinde güvenlik görevlilerinin bulunduğu bir bahçenin içerisinde bina ile kazı yapan görevlilere ait olduğu anlaşılan birkaç yapı tespit edilmiştir. Diğer yandan Miletos'ta, gişe, müze satış mağazası ile kullanım dışı ve kapalı olan bir ofisin var olduğu, Priene'de ise otopark ve tuvaletlerin bulunduğu alanda bir adet gişe ofisinin olduğu ancak bu ofislerin güvenlik görevlilerine tahsis edilip edilmediği tam olarak anlaşılmamıștır.

6- $\quad$ Ören yerinde çalışan güvenlik personeline yönelik mesai saatleri dışında herhangi bir vardiya sistemi uygulanmakta midır?

Akşam saatlerinde gerçekleştirilen gözlemlerde 5 ören yerlerinde (Magnesia, 20.50; Alinda, 19.00; Alabanda, 19.31; Miletos, 18.54; Priene, 19.39) herhangi bir güvenlik görevlisi/ bekçinin olmadığ ancak Didyma'da bir adet güvenlik görevlisinin akşam vardiyasında çalıştı̆̆ 1 her iki gözlemci tarafindan not edilmiştir. Diğer yandan Miletos ören yerinde saat 18.59 'da motosikletli bir şahsın İlyas Bey Külliyesi'nden çıkarak gişe ofisinin yanına motorunu park ettiği, karanlıkta elinde bir torba ile tiyatro yapısının arkasına gittiği ancak döndüğünde elinde herhangi bir torbanın olmadığı, söz konusu şahsın daha sonra Kervansaray'a yöneldiği, 25 dakika kadar beklenmesine rağmen dışarı çıkmadığı 1 nolu gözlemci tarafindan not edilmiştir.

7- $\quad$ Ören yerinde, çevre izleme ve takip sistemi (kamera, drone vb.) kullanulmakta midır?
6 ören yerinin 3'ünde (Magnesia, Alinda, Alabanda) herhangi bir çevre izleme ve takip sistemi tespit edilmemiştir. Miletos'ta, 2 adet gişe kulübesinde ve müze binasında; Didyma'da, giriş kapısında 2 adet; Priene'de gişe binasında 2 adet kameranın olduğu ancak bunların dışında ören yeri içerisinde herhangi bir çevre izleme ve takip sisteminin olmadığı her iki gözlemci tarafindan kaydedilmiştir. Diğer yandan Magnesia'da herhangi bir çevre izleme ve takip sisteminin varlığ1 gözlemlenmemesine rağmen Devlet Agorası'nın etrafını çevreleyen tel örgüye asılı halde bulunan ve üzerinde "Ören yeri güvenlik kameraları ile izlenmektedir" yazısı 1 nolu gözlemci tarafindan not edilmiştir.

8- Ören yerindeki eserlerin korunmasina yönelik herhangi bir alarm sistemi var midır?

6 ören yerinin 3'ünde (Magnesia, Alinda, Alabanda), ören yeri içerisinde bulunan eserlerin korunmasına yönelik herhangi bir alarm sisteminin olmadiğ 1 her iki gözlemci tarafindan kaydedilmiştir. Diğer yandan 2 ören yerinde (Didyma, Priene) yalnızca ören yeri girişinde bulunan gişe/güvenlik ofisi olarak kullanılan yapılarda bir alarm düzeneğine rastlanırken 1 ören yerine (Miletos), gişe/güvenlik ofisinin yanı sıra müze binasının kapısında bir alarm sisteminin var olduğu her iki gözlemci tarafından not edilmiştir.

9- Ören yerinde kazl faaliyetlerinin sürdürülmesi ve güvenliğin sağlanması amacıyla elektrik verilmekte midir?

1 ören yerinde (Alinda) kazı faaliyetlerinin sürdürülmesi ve güvenliğin sağlanması amacıyla herhangi bir elektrik teçhizatına rastlanmazken 3 ören yerinin (Magnesia, Miletos, Didyma) muhtelif yerlerinde elektrik kablolarının olduğu her iki gözlemci tarafından not edilmiştir. Bunun yanı sıra Miletos İlyas Bey Külliyesi ile Didyma Apollon Tapınağı giriş merdiveninin son basamaklarında bir elektrik panosu tespit edilmiştir. Alabanda'da, ören yerine elektrik verilip verilmediği 1 nolu gözlemci tarafindan gözlemlenemezken güvenlik görevlilerinin yer aldığı binanın bahçesinde elektrik kablolarının olduğu 2 nolu gözlemci tarafından gözlemlenebilmiştir. Priene'de ise hem ören yeri içerisinde hem de otopark alanında elektrik kablolarının olduğu 1 nolu gözlemci tarafından not edilirken 2 nolu gözlemci, ören yeri girişinde yer alan elektrik direklerinin varlığına dikkat çekmiştir. 
10- Ören yerinde aydinlatma sistemi var midir? Varsa ne düzeydedir?

6 ören yerinin 2'sinde (Alinda, Alabanda), herhangi bir aydınlatma sisteminin olmadığ 1 tespit edilmiştir. Magnesia'da, gündüz vaktinde yapılan gözlemlerde, ören yeri girişinde yer alan ofisin bulunduğu mevkide aydınlatma lambaları gözlemlenirken akşam 20.50'de gerçekleştirilen gözlemlerde, ören yerindeki aydınlatma lambalarının yanmadığı; Miletos'ta gündüz vakti yapılan gözlemlerde ören yeri girişi ile müze arasında elektrik direklerine bağlı sokak lambalarının olduğu ancak akşam saatlerinde yaklaşık 30 dakikalık gözlem boyunca herhangi bir aydınlatmanın aktif olmadığı her iki gözlemci tarafından tespit edilmiştir. Priene'de tiyatro yapısının girişine bir aydınlatma lambasının olduğu, lambanın elektrik direğine ek kablo ile bağlandığı ancak akşam 19.39'da yapılan gözlemlerde, giriş kapısının kapalı olması nedeniyle tiyatro önünde yer alan aydınlatmanın aktif olup olmadığı 1 nolu gözlemci tarafından tespit edilememiştir. Güllübahçe Mahallesi'nden otoparka uzanan yol üzerinde elektrik direklerine bağlı bulunan lambaların aktif olduğu, Priene otoparkinın ortasinda yer alan lambanın gözlemcilerin yaklaşmasıyla birlikte aktif hala geldiği kaydedilmiştir. Diğer yandan Didyma'da, Apollon Tapınağı'nın her bir yanını çevreleyen 10 adet spot 1şı̆̆ 1 ile ören yerini çevreleyen yolun üzerinde sokak lambalarının olduğu ve akşam saatlerinde gerçekleştirilen gözlemlerde bütün aydınlatma 1şıkların aktif olduğu her iki gözlemci tarafından not edilmiştir.

11- Ören yerinde olass elektrik kesintisinde kullanilabilecek herhangi bir teçhizat (jeneratör gibi) var midir?

4 ören yerinde (Magnesia, Alinda, Alabanda, Priene), olası bir elektrik kesintisinde devreye girebilecek herhangi bir teçhizat (jeneratör gibi) tespit edilmezken 2 ören yerinde (Miletos, Didyma), gişe ofisinin olduğu istikamette birer adet jeneratörün var olduğu her iki gözlemci tarafindan tespit edilmiştir.

12- Ören yerini ziyaret edenlerin paket ve çantalarl, herhangi bir kontrolden (x-ray cihazl, el dedektörü, $x$-ray metal kapı dedektörleri gibi) geçmekte midir?

6 ören yerlerinin tamamında, ziyaretçilerin paket ve çantalarının ören yeri girişinde herhangi bir kontrolden (x-ray cihazı, el dedektörü, x-ray metal kap1 dedektörleri gibi) geçirilmediği her iki gözlemci tarafindan kaydedilmiştir.

13- Ören yerinde sabotaj, yangın, hirsızlık $v b$. durumlara yönelik herhangi bir önlem alınmış midır?

6 ören yerlerinin tamaminda olası bir sabotaj, yangın veya hırsızlık karşısında alınan herhangi bir önlemin alınmadığı her iki gözlemci tarafından not edilmiştir.

14- Ören yerinde üzerine basilan ve koruma altına alınmamış herhangi bir eser var mıdır?

Gözlem yapılan ören yerlerinin tamamında (Magnesia, Alinda, Alabanda, Miletos, Didyma, Priene) üzerine basılan ve koruma altına alınmayan eserler tespit edilmiştir. Magnesia Ören Yeri'nde, Artemis Sunak Alanı zemininde bulunan yazı ve şekillerin etrafının koruma altına alınmadığı; Priene ören yeri içerisinde bulunan Athena Tapınağı ile Meclis Binası etrafında yer alan eski dönemlere ait olduğu bilinen mermerleri korumaya yönelik herhangi bir önlemin alınmadığ Didyma'da, örne yerinin bütününde kabartma ve yazitların var olduğu ancak bu eserlerin üzerine rahatlıkla basılabilecek bir durumda olduğu her iki gözlemci tarafindan not edilmiştir. Bunun yanı sıra, Magnesia ören yerinde Çarşı Bazilikası olarak bilinen yerde, parçalara ayrılmış halde bulunan bir amfora; Alinda ören yerinde $\mathrm{Su}$ Kemerleri, Gözetleme Kulesi, Antik Tiyatro, Agora güzergâhında, kapağı açık ve içi boş durumda olan 10'dan fazla Karia Tipi Lahit Mezar; Alabanda Ören Yeri'ndeki Zeus Khyrsaoreus Tapınağı'nda kuzeyde ve güneyde yer alan 2 tane sütunun taban bölümlerinde " $\Delta \mathrm{I}$ " şeklinde bir yazının koruma altına alınmadığı 1 nolu gözlemci tarafindan kaydedilmiştir.

15- $\quad$ Ören yeri içerisinde girilmesi yasak olan yerlere yönelik herhangi bir uyart levhası konulmuş mudur? Var ise bu uyarllar, hangi dillerde yazılmıştır?

2 ören yerinde (Alinda, Miletos) girilmesi yasak olduğu belirtilen herhangi bir uyarı levhasına rastlanmamıştır. Ancak Magnesia'da, Devlet Agoras1 ile Kütüphane'ye ait koruma tel örgülerinin üzerinde 1 adet, Artemis Sunak Alanı içerisinde su birikintisi olan iki çukur alanın başında 1 adet olmak üzere İngilizce ve Türkçe dillerinde "Dikkat, Girmek Tehlikeli ve Yasaktır" yazılı toplamda 2 adet uyarı levhası, 1 nolu gözlemci tarafından not edilmiştir. Alabanda'da, Agora bölümünde Türkçe dilinde; Priene'de Misır 
Tanrıları Alanı'nda hem Türkçe hem İngilizce dilinde yazılan "Dikkat Kazı Alanı Girilmez" şeklinde uyarı levhaları kaydedilmiştir. Didyma'da ise Kehanet Odası'nın demir bariyerle korunduğu, Tapınak girişinde yer alan Medusa kabartmalı sütun başlığının yanı sıra bazı sütun başlıklarının önüne demir zincir konulduğu ancak bunun dişında girilmesi yasak olduğu belirtilen herhangi bir uyarı levhasına yer verilmediği 1 nolu gözlemci tarafindan not edilmiştir.

16- Ören yerinde dokunulmast yasak olan eserlere yönelik herhangi bir uyarı levhast konulmuş mudur? Var ise bu uyarlar, hangi dillerde yazılmıştır?

5 ören yerinde (Magnesia, Alinda, Alabanda, Miletos, Priene) yapılan gözlemlerde dokunulması yasak olduğu belirtilen herhangi bir esere rastlanmazken Didyma'da yapılan gözlemlerde Apollon Tapınağı'nın arka cephesinde Türkçe, İngilizce ve Almanca dillerinde "“Duvara yazı yazmak yasaktır, Please do not write on the walls, bitte nicht auf die wande schreiben" yazılı bir uyar1 levhasının olduğu her iki gözlemci tarafından kaydedilmiştir. Bunun yanı sıra, Priene'de yapılan gözlemlerde Athena Tapınağı içerisinde 2 adet; Didyma Apollon Tapınağı'nın arka kısmında 1 adet üzerinde hem Türkçe hem de İngilizce dilince "Dikkat, Attention" yazılı uyarı levhalarının olduğu 1 nolu gözlemci tarafindan tespit edilmiştir. 17- Ören yeri içerisinde girilmesi yasak olan yerlere giren herhangi bir ziyaretçi var mıdır? Var ise bu ziyaretçilere gerekli müdahalede bulunulmuş mudur?

Gözlemler esnasında farklı turistler tarafindan ziyaret edilen 3 ören yerinden (Didyma, Miletos, Priene) 1'inde (Priene), gözlemlenen 15 ziyaretçiden girilmesi yasak olan yerlere girmeye teşebbüs eden herhangi bir ziyaretçi gözlemlenmezken Didyma'da, 13 ziyaretçiden 2 'sinin Adyton bölümünü çevreleyen duvarların üstüne çıktıkları ve bu duruma herhangi bir müdahalede bulunulmadığı, bekçinin bizzat gözlemciler tarafindan uyarılması sonucunda bu ziyaretçilerin duvardan indirildiği her iki gözlemci tarafından kaydedilmiştir. Bunun yanı sıra, 1 nolu gözlemci Miletos'ta, Delphinion ve Liman Anitı arasinda otlamakta olan koyunlara herhangi bir müdahalede bulunulmadığına dikkat çekerek Kervansaray ve Külliye arasında bulunan arazide zeytin toplamakta olan 2 şahıs tespit etmiştir. Benzer şekilde Alinda'da, Su Kemerleri ile
Gözetleme Kulesi arasında 3 yaşlı kadının, zeytin ağaçlarından zeytin topladıkları 1 nolu gözlemci tarafindan kaydedilirken 3 ören yerinde (Magnesia, Alinda, Alabanda) herhangi bir ziyaretçinin olmaması nedeniyle bu değişken gözlemlenememiştir.

18- Ören yerinde dokunulmast yasak olan eserlere dokunan herhangi bir ziyaretçi var midır? Var ise bu ziyaretçilere, gerekli müdahalede bulunulmuş mudur?

3 ören yerinde (Miletos, Priene, Alinda), dokunulması yasak olduğu belirtilen herhangi bir esere rastlanmaması; Magnesia ve Alabanda'da ise herhangi bir ziyaretçinin ören yerinde olmaması nedeniyle bu değişken gözlemlenememiştir. Ancak Magnesia'da, hem ören yeri içerisinde hem de Devlet Agorası'nı çevreleyen tel örgünün üzerinde; Didyma'da ören yeri girişinde "esere tırmanmanın, eseri karalayıp çizmenin, ören yerine çöp atmanın ve ören yerinde sigara içmenin yasak olduğu" 4 adet fotoğraf ile belirtilen bir uyarı levhası; Alabanda'da ise ören yeri girişine dönülen yol üzerinde 2863 sayılı Kanun'un 65. Maddesi'nin yazılı olduğu bir uyarı levhası 1 nolu gözlemci tarafindan not edilmiştir.

19- $\quad$ Ören yeri ziyareti esnasında sigara içmeye yönelen herhangi bir ziyaretçi var midır? Var ise bu ziyaretçiye herhangi bir müdahalede bulunulmus mudur?

6 ören yerinin 3'ünde (Didyma, Miletos, Priene), hem İngilizce hem de Türkçe dilinde yazılan "Sigara İçilmez/ No Smoking" şeklinde uyarı levhalarının bulunduğu kaydedilirken Didyma'da ören yeri girişinde merdivenlerin bitiminde yere sabitlenmiş şekilde 1 adet; Priene'de, giriş kapısında 2 adet ve tiyatro yapısının üstünde 1 adet olmak üzere toplam 3 adet; Miletos'ta, Tiyatronun üstündeki ile giriş kapısındaki levha olmak üzere toplam 2 adet uyarı levhası 1 nolu gözlemci tarafindan not edilmiştir. 3 ören yerinde (Magnesia, Alabanda, Alinda), herhangi bir ziyaretçi olmaması nedeniyle bu değişken gözlemlenemezken 2 ören yerinde (Miletos, Priene), sigara içmeye teşebbüs eden herhangi bir ziyaretçinin olmadığı görülmüştür. Ancak Didyma'da, Kehanet Odası'ndan Adyton'a inen merdivenlerin en üst basamağında 3 ziyaretçinin oturduğu ve bu ziyaretçilerden birinin sigarasını içmeyi henüz bitirip izmaritini alt taraftaki basamaklara firlattığ 1 ve bu duruma herhangi bir müdahalede bulunulmadığı 1 nolu gözlemci 
tarafından not edilmiştir. Bunun yanı sıra 1 nolu gözlemci, Alinda'da, Su Kemerleri ile Gözetleme Kulesi arasında 3 farklı noktada ateş yakıldığını; Priene'de ve Didyma'da muhtelif yerlerinde sigara izmaritlerinin olduğunu tespit etmiştir.

\section{SONUÇ VE TARTIŞMA}

Aydın ili sınırları içerisinde yer alan ören yerlerinin güvenlik düzeylerini ortaya koymay 1 amaçlayan bu çalışmada, öncelikle Kültür ve Turizm Bakanlığı'na bağlı Teftiş Kurulu Başkanlığg'nın 2863 Sayılı Kültür ve Tabiat Varlıklarını Koruma Kanunu mevzuatı (Kültür ve Tabiat Varlıklarını Koruma Kanunu, 1983), Kültür ve Turizm Bakanlığı Yatırım ve İşletmeler Genel Müdürlüğü'nün (Kültür ve Turizm Bakanlığ1 Yatırım ve İşletmeler Genel Müdürlüğü, 2019a) ve Türkiye Cumhuriyeti İçişleri Bakanlığı Emniyet Genel Müdürlüğü Kaçakçılık ve Organize Suçlarla Mücadele Daire Başkanlığı'nın 2013 ve 2018 yıllarında hazırlanan raporları (Emniyet Genel Müdürlüğü Kaçakçılık ve Organize Suçlarla Mücadele Daire Başkanlığı, 2014, 2019) incelenerek bir gözlem formu oluşturulmuştur. Sonrasında oluşturulan gözlem formundaki ifadelerle ilgili uzman görüşüne başvurulmuştur. Daha sonra ise, Aydın ili sınırları içerisinde yer alan 8 ören yeri, bu gözlem formu çerçevesinde incelenmiştir.

Ören yeri koruma alanının "muhafaza altına alınmasına" yönelik oluşturulan birinci alt araştırma sorununa ilişkin gerçekleştirilen gözlemlerde, 8 ören yerinden 2'sinin tamamen tel örgülerle koruma altına alındığ 1,6 ören yerinin ise kısmen tel örgüyle çevrildiği ya da herhangi bir koruma önleminin alınmadığı tespit edilmiştir. Ayrıca yapılan gözlemlerde tel örgülerle çevrilmeyen 2 ören yerinde küçükbaş hayvanların otlatıldığına rastlanmıştır. Öztürk'e (2016: 101) göre, ören yerlerinin tel örgü ile çevrelenmesi için öncelikle kamulaştırılması gerekir, kamulaştırma olmadan tel örgü ile muhafaza altına almak zor bir süreçtir ve bu durum da alanı korumasız bir hale getirmektedir. Dolayısıyla bu çalışmada, ören yerlerinin birçoğunun etrafının tel örgüyle çevrili olmamasını Öztürk'ün (2016) ifade ettiği kamulaştırma meselesine bağlamak mümkündür. Ören yerlerinin korunma alanının muhafaza altına alınması için ilk önce mülk sahibinden satın alınarak kamulaştırılması gerektiği ve bunun için de devlet tarafından Kültür ve Turizm Bakanlığı'na tahsis edilen ödeneğin miktarının çok önemli olduğunu söylemek mümkündür.

Ören yeri iç bölgesinde yerleşim katmanlarını tehdit eden herhangi bir imar faaliyetinin olup olmadığını belirlemeye yönelik oluşturulan ikinci alt araştırma sorusuna ilişkin genel bir değerlendirme yapıldığında; 8 ören yerinden 4'ünde, yerleşim katmanına zarar verebilecek herhangi bir imar faaliyetine rastlanmazken 4 ören yerinin içerisinde ve etrafında yerleşim yerleri (ev vb. yapilar) olduğu tespit edilmiştir. Arslan'a (1991) göre çoğu şehir merkezi, eski dokuların üzerinde yer almakta ve antik kentlerin üzerinde oteller, konutlar ve sanayi tesisleri bulunmaktadır. Sınırları içerisinde özel mülklerin yer aldığı bir ören yerinde (Alabanda), hayvancılık faaliyetlerinin yürütüldügüne bakılacak olursa tarihi yapıların korunmasının risk altında olduğu söylenebilir. Söz gelimi Ertaş (1991), insanların ören yerindeki toprağı ekip biçtiğini, taşları söküp kullandığını, sikke vb. eserleri bulup sattıklarını, hayvanları ören yerinde otlattıklarını belirterek insanların ören yerlerini doğanın bir parçası olarak gördüğünü ve faydalanmak istediğini vurgulamıştır. 2863 sayılı Kültür ve Tabiat Varlıklarını Koruma Kanunu'nun 15. maddesinin a bendinde korunması gerekli taşınmaz kültür varlıklarının ve korunma alanlarının Kültür ve Turizm Bakanlığı tarafından hazırlanacak programlara göre kamulaştırılabileceği ve bunun için Bakanlığa yeterince ödenek verileceği belirtilmektedir. Yine 15. maddenin $\mathrm{f}$ bendinde korunması gerekli taşınmaz kültür varlıklarının yer aldığ1 parsellerin arazi sahibinin başvurusu dahilinde kendisine takas edilebileceği bir başka bir kamu parseli verilebileceği belirtilmiştir (Kültür ve Tabiat Varlıklarını Koruma Kanunu, 1983). Neticede, ören yerlerinin kamulaştırılmasının veya arazilerin takas edilmesinin henüz çoğu ören yerinde gerçekleşemediğini belirtmek mümkündür. Aliefendioğlu ve Tanrıvermiş (2011), Türkiye'de arkeolojik ve doğal sit alanları için yapılan kamulaştırma ve takas faaliyetlerinin ödenek yetersizliğinden dolayı yavaş ilerlediğine işaret etmiştir.

Ören yeri korunmasına yönelik oluşturulan 3. alt araştırma sorusuna yönelik bir değerlendirme yapıldığında; 8 ören yerinin 8 'inde de güvenlik personelinin bulunduğu bu 8 ören yerinin 2 'sinde 
sadece müze binasında güvenlik personelinin bulunduğu ve 2 ören yerinde örenyeri korunmasından sorumlu olduğu kişinin üniformas1 olmamasından ötürü güvenlik görevlisi ya da bekçi olup olmadığının anlaşılamadığı tespit edilmiştir. Ören yerlerinde görevli bulunan güvenlik görevlilerinin sayıca az olması bu çalışmanın öne çıkan bulguları arasında yer almaktadır. Kültür ve Turizm Bakanlığ 1 Anıtlar ve Müzeler Kurulu (2003) raporuna göre, Bakanlığa bağlı müze ve ören yerlerinde bekçi ve güvenlik sayısının yetersizliğine vurgu yapılarak bu eksikliğe bağl1 olarak arkeolojik alanlardaki tahribat ve kaçakçılık faaliyetlerinin günden güne arttığ 1 vurgulanmıştır. Benzer şekilde Akkuş (2009: 112), müze ve ören yerlerinde görevli mevcut güvenlik personelleriyle tarihi eser kaçakçılığını ve tahribatını önlemenin mümkün olmadığını öne sürmüştür. Ayrıca ören yerleri içerisinde önemli olan bir başka husus kamera sistemidir. Yapılan bu araştırmada 8 ören yerinin 1'inde hem giriş hem de ören yeri iç kısımlarında yeterli düzeyde kamera olduğu, 4 'ünde iç kısımlarda kamera olmayıp sadece girişste ve gişede kamera yer aldığı; 3 ören yerinde ise hiçbir kamera vb. çevre izleme ve takip sisteminin olmadığı tespit edilmiştir. Akkuş'un (2009: 115), Emniyet Genel Müdürlüğü yetkilisi ile yaptığ 1 görüşmede, müze ve ören yerlerinde yeterince koruma görevlisi ve kamera kontrol sisteminin olmamasının tarihi eser kaçakçılığının çoğalmasının nedenleri arasında gösterilmiştir. Dolayısıyla yapılan bu çalışmada, kamera gibi çevre izleme ve takip sistemi henüz bulunmayan ören yerlerinin kaçakçılık ve tahribat faaliyetlerine açık olduğu öne çıkan sonuçlar arasındadır.

Ören yerleri güvenliğiyle ilgili önemli unsurlardan bir diğeri ise mesai saatleri dışında herhangi bir görevlinin olup olmadığı konusudur. Araştırma kapsamında gerçekleştirilen gözlemlerde 8 ören yerinin 1'inde akşam vardiyasına bir adet bekçinin kaldığ 1 , 6'sında güvenlik personelinin akşam vardiyasına kalmasına yönelik herhangi bir uygulamanın olmadığı tespit edilirken 1 ören yerinde ise mesai saatleri sonrası gözlem yapmak mümkün olmamıştır. Kültür ve Turizm Bakanlığ 1 Teftiş Kurulu Başkanlığı'nın yayınladığı Müzecilik Kılavuzu'nda müze ve ören yerlerinin nöbet sistemi ile ilgili bilgi verilirken müze ve ören yerlerinin güvenlik sorumluluklarının müze müdürlüklerinde olduğu, müze müdürü bilgisi olmadan müze ve ören yerlerine mesai saatleri dışında kimsenin alınmayacağından, müze ve ören yerlerindeki vardiya güvenlik personellerinin nöbetlerle ilgili her işlemi nöbet defterine not düşmesi gerektiği belirtilmiştir (Kültür ve Turizm Bakanlığı, 2001). Tüm bu açıklamalara bakıldığında vardiya dışında personel bulundurulabileceğini söylemek mümkündür. Akkuş ve Efe'ye (2016) göre adli olayların yıllar geçtikçe azalmasında; müzelerde güvenlik personelinin sayısının çoğaltılması, güvenlik sistemlerinin kurulmas1, yeniden düzenlenmesi etkili olmuştur. Dolayısıyla güvenlikten sorumlu personel sayısının arttırılmasıyla birlikte ören yerlerinde kaçakçllık ve tahribat faaliyetlerinin azalabileceğini söylemek mümkündür.

Ören yerlerinin korunması ve güvenlik düzeyleriyle ilgili bir başka önemli boyut, ören yerlerini ziyaret eden kişilerin herhangi bir kontrolden geçip geçmediği hususudur. Bu konu, çalışmanın beşinci alt araştırma sorusunu oluşturmaktadır. Yapılan araştırmada 8 ören yerinin tamaminda "x-ray cihazı" veya "el dedektörü" yardımıyla herhangi bir güvenlik kontrolünün gerçekleştirilmediği gözlemlenmiştir. Kap1 ve el dedektörleri genellikle çok sayıda insanın giriş yaptığı binaların girişinde kullanılan sistemlerdir. Kapı dedektörleri hem zamandan hem de personel maliyetinden tasarruf sağlarken el dedektörleri, ziyaretçilerin üzerinde bölgesel arama gerçekleştirilmesini sağlayarak kap1 dedektörlerinin ulaşamadiğ 1 yerlere ulaşabilmektedir (Akınlar, 2012: 53-54). Dolayısıyla ören yerlerinde, kap1 ve el dedektörlerinden yararlanmak, ören yeri güvenliğinin sağlanmasında büyük önem arz etmektedir.

"Olası bir elektrik kesintisi, hırsızlık, sabotaj ve yangın" gibi olağanüstü durumlar karşısında alınan herhangi bir önlemin olup olmadığı hususu, araştırmanın diğer bir alt araştırma sorusudur. 8 ören yerinin 1 'imde yangın dolabı olduğu, 7'sinde ise herhangi bir yangin önleme unsurunun olmadığı; yalnızca 1 ören yerinde hırsızlığ engellemek amaciyla ören yerinin çevresinin kameralarla kuşatıldığı ancak 7 ören yerinde hırsızlığa yönelik herhangi bir önlem alınmadığ1; olası bir elektrik kesintisine yönelik 8 ören yerinin yalnızca 3'ünde, jeneratör sisteminin olduğu tespit edilmiştir. Alarm sistemleri, ören yerlerinin güvenliğinin sağlanmasında başvurulan önemli 
yöntemler arasında gelmektedir. $\mathrm{Bu}$ çalışma neticesinde, 8 ören yerinin 5'inde, yalnızca gișe/ güvenlik ofisinin bulunduğu bölgede alarm düzeneğinin olduğu ancak 3 ören yerinde herhangi bir alarm düzeneğinin olmadığı tespit edilmiştir. Diğer yandan, 8 ören yerinin iç bölgesinin tamaminı kapsayacak herhangi bir alarm düzeneğine rastlanmamıştır. Kültür ve Turizm Bakanlığı Teftiş Kurulu Başkanlığı'nın yayınladığı Müzecilik Kılavuzu'nda müze ve ören yerlerinde alınacak diğer güvenlik önlemleri bölümünde sabotaj ve yangına karşı diğer kurumlarla iş birliği yapılacağı, alarm ve diğer elektronik koruma sistemlerinin faaliyetini müdür yardımcısının kontrol etmesi gerektiği vurgulanmaktadır (Kültür ve Turizm Bakanlığı, 2001). Fakat k1lavuzda ören yerine özgü tüm bu olası durumlar karşısında yapılacaklarla ilgili herhangi bir özel koruma sisteminden bahsedilmemiştir. Akkuş ve Efe (2016) tarafindan Anadolu Medeniyetleri Müzesi yetkilileri üzerine yapılan çalışmada, olası bir hırsızlık, saldırı, yangin ve sel durumunda personelin yapması gerekenlere yönelik bir yönerge hazırlanmasının faydalı olacağı sonucuna ulaşılmıştır. Sonuç olarak ören yerlerinin olası acil durumlar karşısında yapmaları gereken eylemlerin henüz kurumlar tarafindan belirlenmediği, ilgili kılavuzda ören yerlerine özgü konuya dair detaylı bilgilerin yer almadığ 1 ve bunlardan dolayı ören yerlerinde hırsızlık, sabotaj, yangın ve elektrik kesintisi gibi konularda henüz daha eksiklikler olduğunu söylemek mümkündür. Berkok (1991), Türkiye'deki eski eser kaçakçılığının ortaya çıkmasının önemli sorunlardan bazılarını; teknik donanım eksikliği, müzelerin satın alma gücünün düşük olması ve kurumlar arası iş birliği yetersizliği şeklinde sıralamaktadır. Akkuş ve Efe (2016) tarafından gerçekleştirilen çalışmada, teknik desteğin artırılması durumunda hırsızlık faaliyetlerinin azaltılabileceği sonucuna ulaşılmıştır. Dolayısıyla ören yeri yetkililerince, olağanüstü durumlara yönelik gerekli ekipmanları temin etmeleri büyük önem arz etmektedir.

"Ören yerinde uyarı levhaları/ tabelalarının bulundurulup bulundurulmadığı" konusu araştırmanın 7. alt araştırma sorusunu oluşturmaktadır. 8 ören yerinin 6'sında, girilmesi yasak olan yerlere yönelik uyarı levhasına yer verilirken 2 ören yerinde herhangi bir uyar1 levhasının olmadığ sıra, 8 ören yerinin 4'ünde, sigara içmenin yasak olduğunu belirten uyarı levhası/tabelası bulunurken 4 ören yerinde ise herhangi bir uyarı levhasi/tabelasına rastlanmamıştır. Ancak bu uyarı levhalarının ören yerinin tamamına yayılmadığını yalnızca sinırlı sayıda ve bölgede yer aldığını söylemek mümkündür. Kültür ve Turizm Bakanlığı'na bağlı Teftiş Kurulu Başkanlığı'nın yayınladığı Müze ve Ören Yerleri Giriş, Bilgilendirme, Yönlendirme ve Uyarı Tabelalarına İlişkin Yönerge 'ye göre, müze ve ören yerlerine konulan uyarı tabelaları, "Alanda ziyaretçilere yönelik olarak olası tehlikelere dikkat çekmek amacıyla belirlenen yasak ve kisitlamaları belirten grafik ve yazı içerikli tabelalar" şeklinde tanımlanmıştır (Kültür ve Turizm Bakanlığı Teftiş Kurulu Başkanlığ 1 , 2014). Yönergeye göre ören yeri içerisinde en az 2 adet "Sigara İçilmez" uyarı levhası konulması zorunluluktur (Kültür ve Turizm Bakanlığı, 2014). Fakat yönerge içerisinde diğer uyarılarla ilgili herhangi bir zorunluluk belirtilmemiştir. 1 ören yerinde, sigara içen bir ziyaretçiye herhangi bir müdahalenin olmadiğ 1 tespit edilirken 6 ören yerinin muhtelif yerlerine sigara izmaritleri gözlemlenmiştir. Sonuç olarak, ören yerlerinde bulunan ve bulunmas1 gereken uyarı levaları/tabelalarının mevzuata rağmen yeterli şekilde koyulmadığı, bu nedenle de sistemde aksamaların olduğunu söylemek mümkündür. Ören yerlerinin güvenlik düzeylerini belirlemeye yönelik gerçekleştirilen bu araştırma neticesinde elde edilen bulgulardan hareketle:

- Kültür ve Turizm Bakanlığınca kullanılan Kültür ve Tabiat Varlıklarını Koruma Kanunu'nda ören yerlerinin korunmasina yönelik bölümlerin artırılması yararlı olacağı,

- Kültür ve Turizm Bakanlığınca kullanılan Kültür ve Tabiat Varlıklarını Koruma Kanunu'nun 64. maddesindeki ikramiyelerin artırılması, eser kaçakçılığının engellenmesine katkı sağlayabileceği,

- Kültür ve Turizm Bakanlığınca kullanılan Kültür ve Tabiat Varlıklarını Koruma Kanunu'nun 65. maddesindeki yaptırımların artırılmasıyla birlikte kaçakçılığın azaltılabileceği,

- Müzecilik Kılavuzu'nun yanı sıra yalnızca ören yerlerinin güvenliğini temel alan bir kılavuzun çıkarılmasının, tarihi eserlerin korunmasına yardımcı olabileceği, 
- Müzecilik Kilavuzunun içerisine güvenlik görevlisi, bekçi ve koruma hususunda daha kapsamlı açıklamaların koyulmasının yararlı olacağ 1 ,

- Müzecilik Kılavuzu içerisine güvenlik görevlilerinin olası bir durumda kendilerini koruyabilecekleri savunma mekanizmalarıyla (silah, cop vb.) ilgili yer verilmesinin tarihi eserlerin korumasına katkıda bulunabileceği,

- Ören yerlerinin korunmasına yönelik verilen ödeneğin arttırılması ile birlikte tarihi eser kaçakçılığının ve tarihi eser tahribatının yavaşlatılabileceği,

- Ören yerlerinde $7 / 24$ görev yapacak güvenlik görevlilerinin sayılarının arttırılmasının kaçak kazılara olan yönelimi azaltabileceği,

- Ören yerlerinde istihdam edilecek güvenlik görevlilerine, tarihi eser ve kültürel miras konusunda bir eğitim verilmesinin, bu görevlilerin tarihi eser bilincine sahip olmalarına katkı sağlayabileceği,

- Kapı tipi metal dedektörler ile el dedektörlerinin ören yerlerinde kullanılması, tehlikeli araç gereçlerin ören yerleri içerisine alınmasını engelleyebileceği,

- Ören yerindeki eserlere verilecek zararların kanuni yaptırımı olduğunu belirten uyarı levhalarının, ören yerlerinin geneline yayılması, kuralların dışına çıkma eğilimini azaltabileceği,

- Kameraların, yalnızca ören yerlerinin girişinde değil, ören yerlerinin iç bölgelerine de koyulmasinın ve ören yerlerinin "drone" sistemi ile izlenmesinin hırsızlık, kaçakçılık ve tahribatı azaltabileceği,

- Alarm sistemlerinin, yangın müdahale sistemlerinin, aydınlatma sistemlerinin ve jeneratörlerin ören yerinin tamamını kapsayacak şekilde genişletilmesi, acil durumlarda yaşanabilecek muhtemel sorunları azaltabileceği,

- Kamulaştırılmamış olan ören yerlerinin bulunduğu arazilerde, hayvan otlatılmasının yasaklanmasıyla birlikte bu hayvanların, tarihi eserlere verecekleri olas1 tahribatı azaltılabileceği,

- Kültürel mirasın korunması ile tarihi eser kaçakçılığına yönelik eğitim faaliyetleri (seminer, kurs vb.) düzenlenerek halkın bu konuda bilinçlenmesinin sağlanabileceği,
- Ülkemizdeki “izinli definecilik" faaliyetlerinin de tamamen yasaklanmasiyla birlikte yapılacak kazı çalışmaları neticesinde ortaya çıkabilecek olası tahribatın önlenebileceği,

- Kültür ve Turizm Bakanlığı'na ören yerlerinin kamulaştırılması için ayrılan ödeneğin (Basın İlan Kurumu 2019 verilerine göre 2020 y1l için Kültür ve Turizm Bakanlığına ayrılan toplam ödenek 3.512.175.000 Türk Lirası'dır) yükseltilmesiyle birlikte ören yerlerinin tamamının koruma altına alınmasının mümkün olabileceği düşünülmektedir.

Her araştırmada olduğu gibi bu araştırmanın da birtakım sınırlılıklarından söz etmek mümkündür. 2019 yılı Aralık ayında, öncelikle Çin'in Wuhan şehrinde ortaya çıkan COVID-19 salgını, kısa sürede dünya geneline yayılmıştır. Buna bağlı olarak, dünya genelinde olduğu gibi Türkiye'de de turistik hareketlerde bir azalma meydana gelmiştir. Dolayısıyla araştırmanın gerçekleştirildiği dönemin (Ocak-Şubat 2020), bu salgının yayılım gösterdiği döneme rastlaması nedeniyle ören yerlerinde, çok az sayıda ziyaretçi gözlemlenebilmiştir. Araştırmanın Aydın ili sınırları içerisinde yer alan 8 ören yerinde gerçekleştirilmiş olması, çalışmanın bir diğer kısıtını oluşturmaktadır. Gelecekte, farklı illerde yer alan ören yerlerinde gerçekleştirilecek gözlemlerle birlikte, daha kapsamlı sonuçlar ortaya koyulabilir. Ören yerlerinde gerçekleştirilen gözlemlerin sınırlı bir zamanda (yaklaşık 1,5-2,5 saat) gerçekleştirilmiş olması çalışmanın bir diğer kısıtını oluşturmaktadır. Söz konusu ören yerlerinin her birinde, daha geniş bir zaman diliminde yapılacak gözlemlerle farklı sonuçlar ortaya koymak mümkün olabilir. Son olarak çalışmada, veri toplama yöntemi olarak katılımsız gözlemden yararlanılmıştır. $\mathrm{Bu}$ çalışmada öne çıkan bulgulardan hareketle ileride gerçekleştirilecek nicel desenli çalışmalarla daha bütüncül sonuçlar ortaya koyulabilir.

\section{KAYNAKÇA}

Akat, A. (1990). Kültür ve Tabiat Varlıklarını Koruma Kurultayı, Ankara: Kültür Bakanlığı Kültür ve Tabiat Varlıkları Koruma Genel Müdürlüğü Yayınları. 
Akınlar, C. (2012). Bina Giriş Kontrol Sistemleri (ss. 45-54), Güvenlik Sistemleri; (Ed: Oysal, Y.), Anadolu Üniversitesi, Eskişehir.

Akkuş, Z. (2009). Türkiye'de Eski Eser Kaçakçılığı ve Önlenmesinde Ortaya Çıkan Sorunlar. Yüksek Lisans Tezi, Ankara Üniversitesi Sosyal Bilimler Enstitüsü: Ankara.

Akkuş, Z. ve Efe, T. (2016). Türkiye'de Kültür ve Turizm Bakanlığı'na Bağlı Müzelerin Güvenliği ve Polisin Rolünün Değerlendirilmesi, Ankara Üniversitesi Sosyal Bilimler Dergisi, 7(1). 204226

Akturan, U., Ataçkarapınar, M., Ünverdi, K.B., Y1ldı, D. ve Mizan, E. (2013). Gözlem (ss. 99102), Nitel Araştırma Yöntemleri: Nvivo ile Nitel Veri Analizi, Örnekleme, Analiz, Yorum (Edt: Baş, T. ve Akturan, U.). Seçkin Yayıncılık: Ankara.

Aladağ, H. (2010). Kültür Varlıklarının Korunmasında Koruma Yönetimi Süreci. Yüksek Lisans Tezi, Yıldız Teknik Üniversitesi, Fen Bilimleri Enstitüsü: İstanbul

Aliefendioğlu, Y. ve Tanrıvermiş, H. (2011). Türkiye'de Çevre Koruma Alanlarında Arazi Kullanımı Ve Koruma Kararlarının Arazi Piyasalarına Etkileri: Gökova Özel Çevre Koruma Bölgesi Örneği, Üçüncü Sektör Sosyal Ekonomi Dergisi, 46 (1), 64-102.

Altunışık, R., Çoşkun, R., Bayraktaroğlu, S. ve Yıldırım, E. (2010). Sosyal Bilimlerde Araştırma Yöntemleri SPSS Uygulamalı (6. Baskı). Sakarya Yayıncılik: Sakarya

Arslan, G. (1991). Arkeolojik Sit Alanlarının Belgeleme (Tespit-Tescil) Sorunları, Arkeolojik Sit Alanlarının Korunması ve Değerlendirilmesi $I$. Ulusal Sempozyumu, Antalya.

At1lgan, C. (2016). Ulusal ve Uluslararas1 Düzenlemeler Işı̆ğında Türkiye'de Taşınmaz Kültür Varlıklarının Korunması Üzerine Bir Değerlendirme. Art-Sanat Dergisi, 0 (6), 249-261

Basın İlan Kurumu. (2019). Hangi bakanlık ve kuruma ne kadar ödenek ayrıldı? https://www.bik.gov.tr/hangi-bakanlik-ve-kurumane-kadar-odenek-ayrildi-tam-liste-2/, (Erişim Tarihi: 17.01.2020).

Berkok, N. (1991), "Eski Eser Kaçakçılı̆̆ı", Ankara Üniversitesi Dil ve Tarih-Coğrafya Fakültesi Dergisi, 364: 325-339.
Emniyet Genel Müdürlüğü Kaçakçılık ve Organize Suçlarla Mücadele Daire Başkanlığı (2014). Kaçakçılık ve Organize Suçlarla Mücadele 2013 Raporu. KOM Yayılarn: Ankara. https://www.egm.gov.tr/kurumlar/egm.gov.tr/IcSit e/kom/YAYINLARIMIZ/T\%C3\%9CRK\%C3\%87 E/2013\%20RAPORU\%20T\%C3\%9CRK\%C3\%87 E.pdf, (Erişim Tarihi: 29.11.2019).

Emniyet Genel Müdürlüğü Kaçakçılık ve Organize Suçlarla Mücadele Daire Başkanlığı (2019). Kaçakçılık ve Organize Suçlarla Mücadele 2018 Raporu. KOM Yayınları: Ankara. https://www.egm.gov.tr/kurumlar/egm.gov.tr/IcSit e/kom/YAYINLARIMIZ/T\%C3\%9CRK\%C3\%87 E/2018-RAPORU-TURKCE.pdf, (Erişim Tarihi: 29.11.2019).

Ertaş, G. (1991). Yeni Gelişme Alanlarında (Turizm, Sanayi, Tarım vb.) Yer Alan Ören Yerlerinin ve Arkeolojik Değerlerin Sorunları, Arkeolojik Sit Alanlarinın Korunmass ve Değerlendirilmesi I. Ulusal Sempozyumu, Antalya. İhlas Haber Ajans1 (2017). "Aydın'da hırsızlar 2 bin 350 ylllı tarihi çaldılar". https://www.milliyet.com.tr/gundem/aydin-dahirsizlar-2-bin-350-yillik-tarihi-caldilar-2383861 (Erişim Tarihi: 17.01.2020).

Karaduman, H. (2007), Türkiye'de Eski Eser Kaçakçılı̆̆ , Mert Basın Yayın: Ankara.

Karasar, N. (2009). Bilimsel Araştırma Yöntemi (20. Bask1). Nobel Yayın Dağıtım: Ankara.

Kozak, M. (2014). Bilimsel Araştırma: Tasarım, Yazım ve Yayım Teknikleri. Detay Yayıncılı: Ankara.

Kültür ve Tabiat Varlıklarını Koruma Kanunu. (1983). Resmi Gazete (Say1: 2863) 6498 say1l Kanun ile değişik hali. https://www.mevzuat.gov.tr/MevzuatMetin/1.5.28 63-20131008.pdf, (Erişim Tarihi: 30.11.2019).

Kültür ve Turizm Bakanlığı Anıtlar ve Müzeler Kurulu. (2003). Yitik Mirasin Dönüş Öyküsü. Yap1 Kredi Kültür ve Sanat Yayınları, Ankara

Kültür ve Turizm Bakanlığı Teftiş Kurulu Başkanlığı. (1990). Müzeler İç Hizmetleri Yönetmeliği. https://teftis.ktb.gov.tr/TR14442/muzeler-ic-hizmetler-yonetmeligi.html (Erişim Tarihi: 30.11.2019).

Kültür ve Turizm Bakanlığı Teftiş Kurulu Başkanlığı. (2001). Müzecilik Kılavuzu. 
https://teftis.ktb.gov.tr/TR-13998/muzecilikklavuzu.html, (Erişim Tarihi: 30.11.2019).

Kültür ve Turizm Bakanlığ 1 Teftiş Kurulu Başkanlığı. (2014). Müze ve Ören Yerleri Giriş, Bilgilendirme, Yönlendirme ve Uyar Tabelalarına İlişkin Yönerge. https://teftis.ktb.gov.tr/TR107173/muze-ve-oren-yerleri-giris-bilgilendirmeyonlendirme-ve-.html, (Erişim Tarihi: 15.01.2019).

Kültür ve Turizm Bakanlığı Yatırım ve İşletmeler Genel Müdürlüğü (2019a). $2018 \quad$ Turizm Istatistikleri Genel Değerlendirme Raporu, https://yigm.ktb.gov.tr/Eklenti/63643, turizmistatist iklerigeneldegerlendirme2018pdf.pdf?0, (Erişim Tarihi: 29.11.2019).

Kültür ve Turizm Bakanlığ İşletmesi Merkez Müdürlüğü, (2019b). Müze Ve Ören Yeri 2018 Yll Toplam İstatistikleri Raporu, http://www.dosim.gov.tr/assets/documents/2018.pd f, (Erişim Tarihi: 30.11.2019).

Nesli, A. (2018). Eski Eserlerin Korunmasının Hukuk Tarihi Yönüyle İncelenmesi. Dokuz Eylül Üniversitesi Hukuk Fakültesi Dergisi, 20 (1), 431478.

Özel, S. (2005). 5226 Say1lı "Kültür ve Tabiat Varlıklarını Koruma Kanunu İle Çeşitli Kanunlarda Değiş̧iklik Yapılması Hakkında Kanun" Üzerine Bir Değerlendirme. İstanbul
Üniversitesi Hukuk Fakültesi Mecmuasl, 63(1-2), 113-138.

Özmen, S. (2018). Müze Eğitiminin Gelișimi. HUMANITAS- Uluslararasi Sosyal Bilimler Dergisi, 6 (11), 301-324.

Öztürk, H.H. (2016) Arkeolojik Alanların Korunmasinda Planlama Ve Yönetim: Ören Yerlerinin Çevre Düzenlemesi, Doktora Tezi, Ankara Üniversitesi Sosyal Bilimler Enstitüsü Sosyal Çevre Bilimleri Anabilim Dalı: Ankara.

Papaioannou, K. (2017). The International Law on The Protection of Cultural Heritage. IJASOSInternational E-Journal of Advances in Social Sciences, 3 (7), 257-262.

Sabah Gazetesi (2019). “Aydın'da 2 bin 500 yıllık tarihi eser bulundu”. https://www.sabah.com.tr/ galeri/yasam/aydinda-2-bin-500-yillik-tarihi-eserbulundu, (Erişim Tarihi: 17.01.2020).

Töngür, A. R. (2018). Birleşmiş Milletler Konvansiyonları Işı̆̆ında Kültür Varlıklarının Yasadışı Ticaretinin ve Nakillerinin Önlenmesi. Manas Sosyal Araştırmalar Dergisi, 7 (2) 91-110.

Uralman, N.H. (2006). 21. Yüzyıla Girerken Bir Bilgi Kurumu Olarak Müze. Bilgi Dünyası, 7(2), 250-26. 